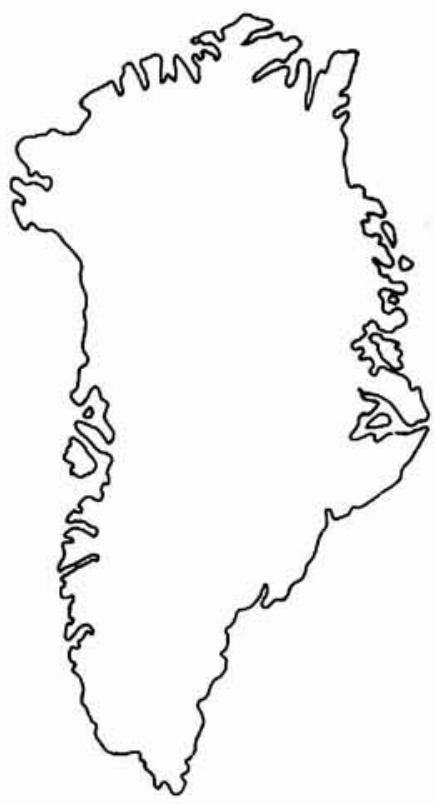

\title{
Tectonostratigraphy of North Greenland
}

\author{
Finn Surlyk
}

\begin{abstract}
A succession of at least eight tectonostratigraphic basins occurs in North Greenland, spanning over 1200 million years from Middle Proterozoic to Tertiary times. They represent major events of plate reorganisation associated with extension or compressional loading of the crust. The tectonostratigraphic basins consist of depositional sequences composed of linked depositional systems. Five major collisional events are recorded which influenced or closed and deformed former basins. The main basins, basin-forming and collisional events are: 1, Middle Proterozoic interior sag (Independence Fjord Basin), c. $1380 \mathrm{Ma}$; 2, Middle Proterozoic rifting and volcanism (Midsommers $\emptyset$ - Zig-Zag Dal volcanic event), c. $1230 \mathrm{Ma}$; 3, Grenvillian Orogeny (no direct evidence preserved), $1100-1000 \mathrm{Ma} ; 4$, Late Proterozoic rifting and opening of the Iapetus Ocean (Hagen Fjord - Rivieradal passive margin basin), c $800($ ?)-590 Ma; 5, latest Proterozoic - earliest Cambrian rifting, and Early Palacozoic passive margin (Franklinian Basin), c. 640?-380 Ma; 6, early Caledonian accretionary event causing formation of a westwards migrating peripheral bulge (terminated in the Early Ordovician), $480 \mathrm{Ma} ; 7$, early onset of Caledonian orogenic uplift, c. 435 Ma; 8, latest Silurian - Early Devonian final Caledonian suturing, and westwards nappe transport and formation of a Caledonian foreland basin (not preserved), c. 410 Ma; 9, Late Devonian - Early Carboniferous closure of the Franklinian Basin (Ellesmerian Orogeny) and formation of a foreland basin (not preserved), c. $360 \mathrm{Ma}$; 10, Early Carboniferous - Middle Permian rifting of the northern extension of the East Greenland rift basin, 360-260 Ma; 11, Mesozoic (Triassic, Late Jurassic Cretaceous) oblique-slip basin, 250-80 Ma; 12, Late Cretaceous rifting (Eurasia Basin), 80-65 Ma; 13, Eurekan thrusting and faulting, 65-55 Ma; 14, Early Tertiary initiation of transform margin basin, 55-0 Ma. Each basin fill constitutes a tectonostratigraphic basin and reflects a major plate tectonic event. The indicated ages are in most cases crude approximations only.
\end{abstract}

F. S., Geological Central Institute, University of Copenhagen, Øster Voldgade 10, DK-1350 Copenhagen K, Denmark.

A coherent tectonic and stratigraphic picture of the geological evolution of North Greenland has emerged after a decade of systematic mapping and topical studies by the Geological Survey of Greenland (GGU) in cooperation with groups from the University of Copenhagen and various non-Danish institutions (Figs 1,2). These studies represent the culmination of a long exploration history, with field work often carried out under harsh conditions (see Henriksen \& Higgins, 1991).

It is now possible to distinguish a succession of at least eight major separate tectonostratigraphic basins ranging in age from Middle Proterozoic to Tertiary and in most cases separated by episodes of deformation (Figs 2, 3). The basins correspond to plate tectonic events and periods of plate reorganisation and they are thus categorised as first order, tectonostratigraphic units in a hierarchy of basinal stages. Several of the tectonic episodes overlap temporally and have direct interrelations in terms of controlling sedimentation and subsidence or uplift histories. This is particularly the case with the interplay in eastern areas of North Greenland between the passive margin evolution of the Franklinian Basin and Caledonian closure of the Iapetus Ocean (Surlyk \& Hurst, 1983, 1984; Hurst et al., 1983; Surlyk, 1988).

\section{Precambrian crystalline basement}

In North Greenland and adjacent North-West Greenland crystalline basement is exposed in several areas (Map 1). In Inglefield Land Proterozoic crystalline rocks are overlain by Proterozoic and Cambrian sediments (e.g. Peel et al., 1982). At the head of Victoria Fjord, along the margin of the Inland Ice, Archaean gneisses are overlain by flat lying sediments of the Up- 





Middle Proterozoic rifting and volcanism

+ Zig-Zag Dal Basalt Fm

Middle Proterozoic interior sag

E. Independence Fiord Group (includes intrusive volcanics of the Midsommerse Dolerite Fm)

遥微 Archaean and Proterozoic crystalline basement

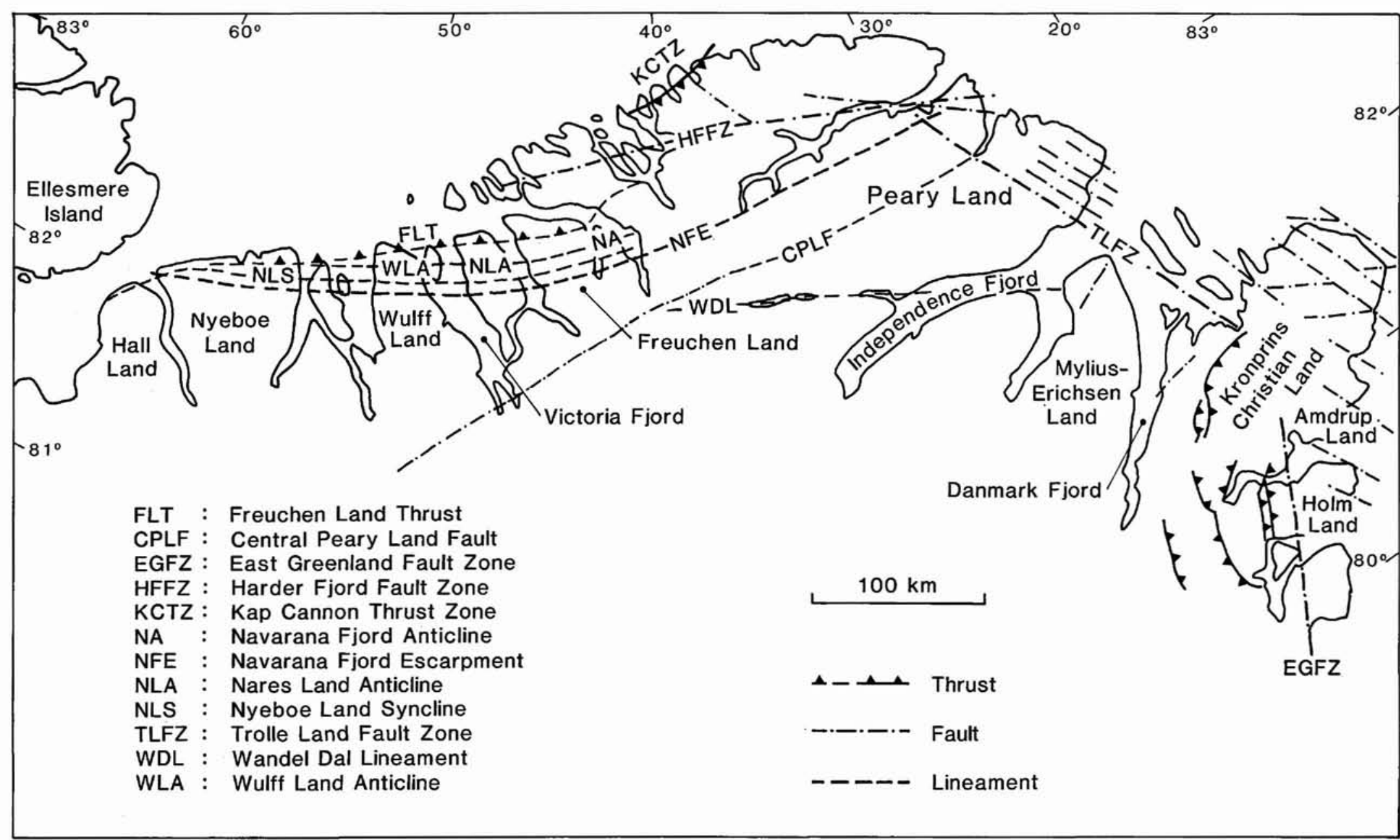

Fig. 1. Simplified geological map of North Greenland showing main structural features (below). Based on various GGU maps and other published sources. The term Freuchen Land Thrust is introduced to replace the slightly inappropriate Buen Thrust of Soper \& Higgins (1990). 


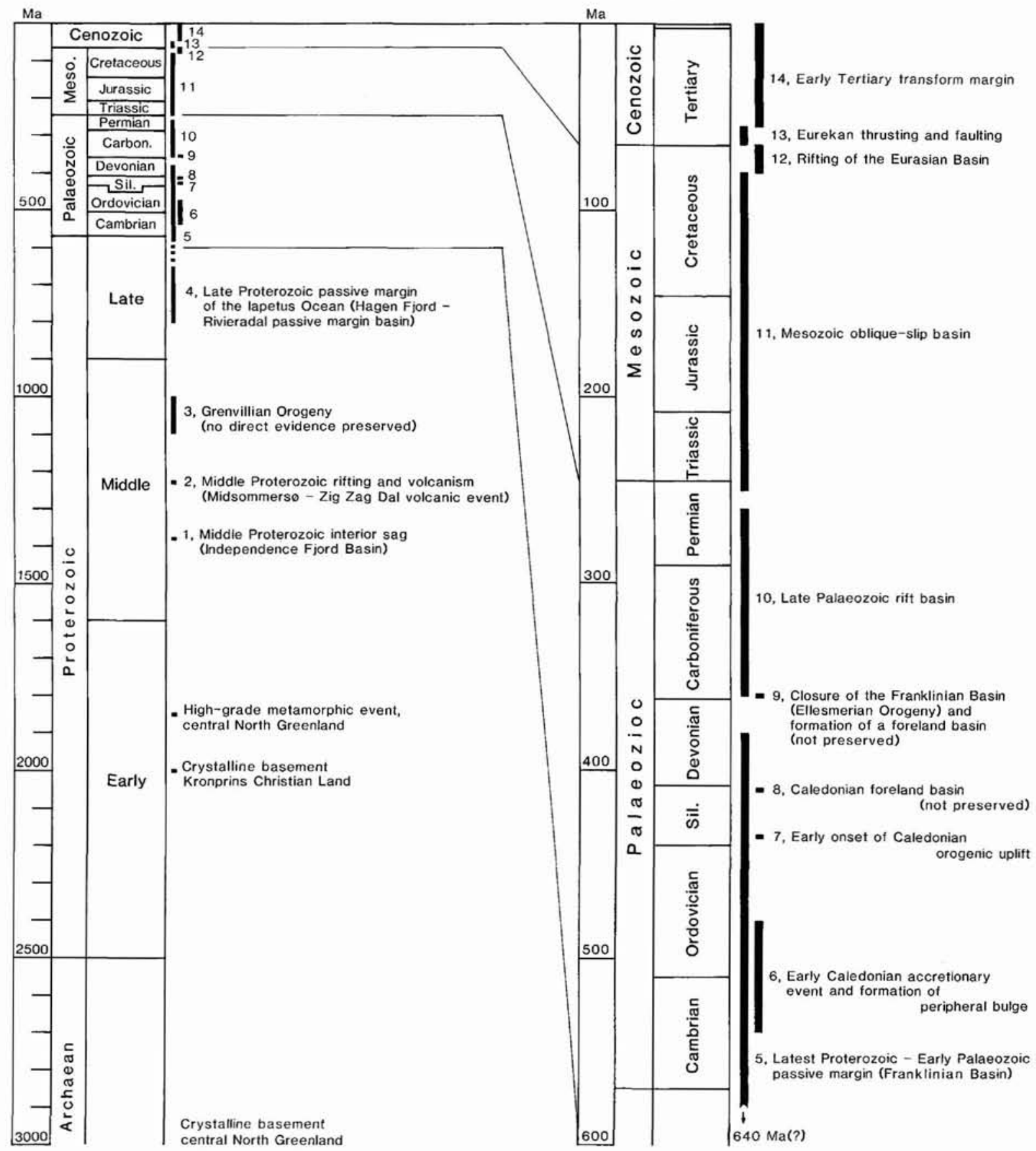

Fig. 2. Tectonostratigraphic basins and collisional events in North Greenland.

per Proterozoic Morænesø and the Lower Cambrian Portfjeld Formations. Zircon, U/Pb and $\mathrm{Rb} / \mathrm{Sr}$ wholerock isotope data give Archaean ages (c. $3000 \mathrm{Ma}$ ) for the basement, but $\mathrm{K} / \mathrm{Ar}$ analyses on hornblende show that the area underwent a phase of high-grade metamorphism during the Proterozoic, probably around
$1850 \mathrm{Ma}$ (Hansen et al., 1987). Along the east coast of Kronprins Christian Land Proterozoic crystalline basement (c. $2000 \mathrm{Ma}$ ) is overlain by Middle Proterozoic sandstones of the Independence Fjord Group (c. 1380 $\mathrm{Ma})$. It is uncertain whether the crystalline rocks of Victoria Fjord form the extension of the Archaean 
basement beneath the Rinkian and Caledonian fold belts, or whether they are separated from these by an area of Proterozoic crust (Hansen et al., 1987).

\section{1, Middle Proterozoic interior sag (Independence Fjord Basin), c. $1380 \mathrm{Ma}$}

The earliest preserved sedimentary basin in North Greenland is represented by the Middle Proterozoic Independence Fjord Group (Figs 3A, 4) (Sønderholm \& Jepsen, 1991). Clays within the middle part of the group have yielded $\mathrm{Rb} / \mathrm{Sr}$ ages around $1380 \mathrm{Ma}$. The group is more than $2 \mathrm{~km}$ thick and is inferred to rest unconformably upon Archaean crystalline basement. It consists of the geographically-separated, sandstonedominated Inuiteq $S \varnothing$ and Norsemandal Formations. The group is dominated by sandstones which were deposited in fluvial and aeolian environments on very low angle alluvial fans possibly forming bajadas. Relative rises in base level resulted in the formation of ephemeral saline lake and playa systems which are represented by several laterally extensive siltstone members. The exact nature of the basin is not known. The uniformity of the continental deposits, the great lateral extent of the facies and the apparent lack of syn-depositional faults suggest that it was an intracratonic sag basin which did not develop into a rift and spreading centre. Collinson (1983) tentatively suggested that minor phases of heating and cooling at depth led to the extensive lacustrine intervals and that a much larger but related thermal event led to the extensive intrusion of dolerite and extrusion of the basalts which directly overlie the Independence Fjord Group.

\section{2, Middle Proterozoic rifting and volcanism (Midsommersø - Zig-Zag Dal volcanic event), c. $1230 \mathrm{Ma}$}

A major volcanic event occurred in the Middle Proterozoic and intrusive and extrusive volcanic rocks are preserved in a more than $100 \mathrm{~km}$ wide belt curving along the present northern and eastern margin of the Canadian-Greenland Shield (Fig. 3B). Huge volumes of basic magma (the Midsommers $\emptyset$ Dolerite Formation) intruded the crystalline basement and the Independence Fjord Group (Kalsbeek \& Jepsen, 1983). Extrusive equivalents covering an area of more than $10000 \mathrm{~km}^{2}$ comprise at least $1350 \mathrm{~m}$ of quartz tholeiitic lava flows forming the Zig-Zag Dal Basalt Formation (Kalsbeek \& Jepsen, 1984). Whole rock $\mathrm{Rb} / \mathrm{Sr}$ data from the intrusives give ages of about $1230 \mathrm{Ma}$. The volcanic event probably represents the onset of rifting and formation of an oceanic spreading centre following the Independ- ence Fjord sag basin. The ocean was apparently situated along the northern margin of the Canadian-Greenland Shield (Jackson \& Ianelli, 1981). It is of pre-Grenvillian age but remains of true oceanic crust are not preserved in North Greenland.

\section{3, Grenvillian Orogeny, 1100-1000 Ma}

The Proterozoic volcanic event was followed by uplift, block-faulting and peneplanation. These processes took place in the long time interval between about 1230 $\mathrm{Ma}$ and the next basin-forming episode which was initiated during the Late Proterozoic (later than $800 \mathrm{Ma}$ ). This hiatus which represents over $400 \mathrm{Ma}$ includes the time interval during which the Grenvillian Orogeny took place $(1100-1000 \mathrm{Ma})$. There is no direct evidence of this collisional orogenic event in North Greenland, but it resulted in intense deformation, metamorphism and plutonic intrusion along the northern margin of the Canadian Shield (Trettin, 1987).

\section{4, Late Proterozoic passive margin of the Iapetus Ocean (Hagen Fjord - Rivieradal basin), c. 800(?)-590 Ma}

The next major basin formation event took place some time between 800 and $590 \mathrm{Ma}$ and is interpreted as heralding the early phases of rifting of the Iapetus Ocean (Figs 2, 3C). The succession includes up to 1000 $m$ of shelf deposits of the Hagen Fjord Group and more than $2500 \mathrm{~m}$ of partly age equivalent basinal turbidites and conglomerates included in the Rivieradal sandstones (Fig. 4; Clemmensen \& Jepsen, in press; Sønderholm \& Jepsen, 1991).

The Hagen Fjord Group unconformably overlies and onlaps the peneplained Independence Fjord sandstones and Zig-Zag Dal basalts from east to west (Fig. 5). It consists of a lower sandstone dominated part which passes upwards into limestones and dolomites and finally back to sandstones in the upper part (Clemmensen \& Jepsen, in press). The lower onlapping sandstone unit (Jyske Ås Formation) was deposited on a shallow tidally influenced shelf. Palaeocurrent data suggest that the open sea was towards the north-east. The transgressive sandstone unit is followed by variegated mainly peritidal sandstones and siltstones, and shallow subtidal stromatolitic dolostones (Campanuladal and Catalinafjeld Formations).

This phase was followed by a change from siliciclastic to carbonate deposition in the younger part of the group. The change records the development of an incipient carbonate platform (Kap Bernhard Formation), which eventually evolved into a true carbonate platform 
A. Middle Proterozoic interior sag basin
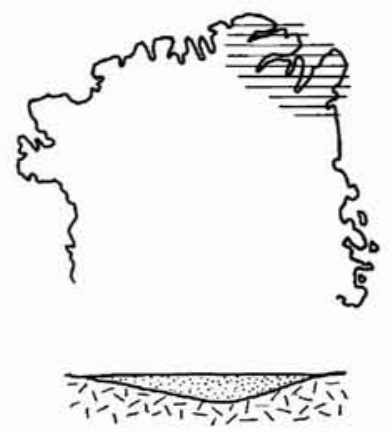

conjectural

D. Latest Proterozoic Early Palaeozoic
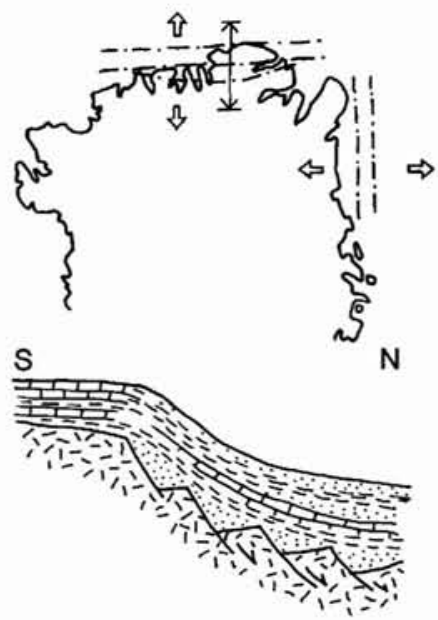

G. Late Palaeozoic rift basin
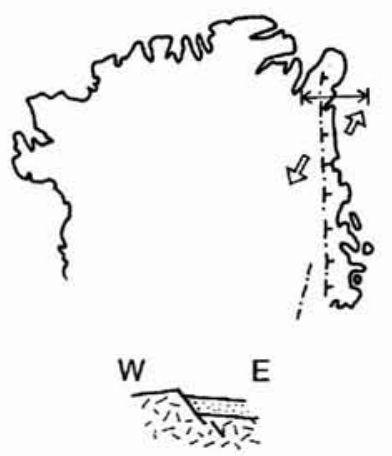

B. Middle Proterozoic rifting and volcanism
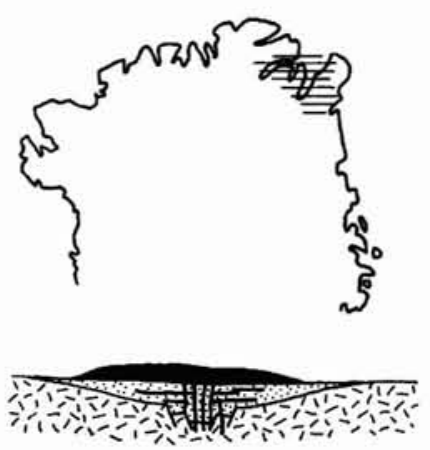

E. Caledonian foreland basin (not preserved)
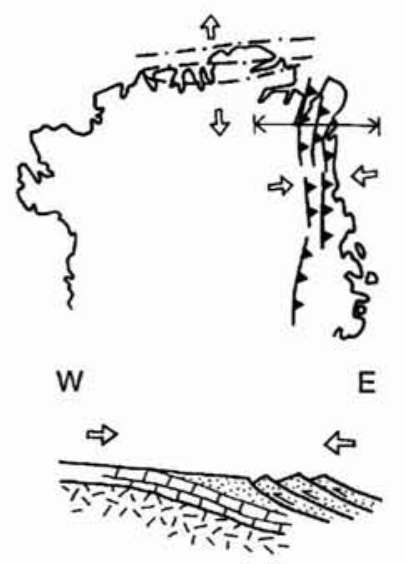

H. Late Palaeozoic Mesozoic basins
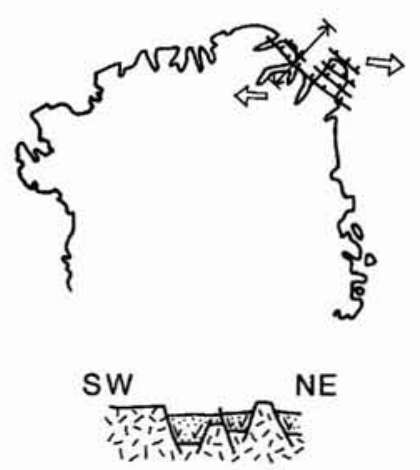

C. Late Proterozoic Iapetus Ocean
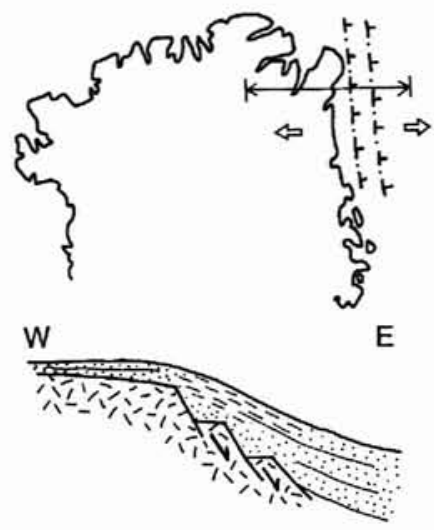

F. Ellesmerian foreland basin (not preserved)

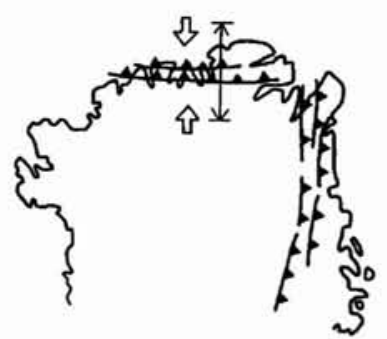

S

$\mathrm{N}$

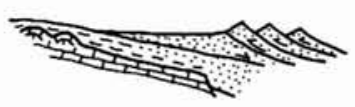

I. Early Tertiary margin

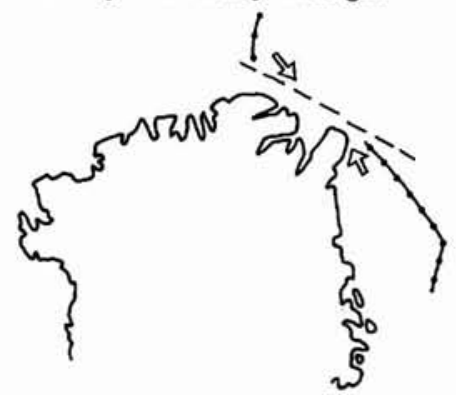

Fig. 3. Schematic maps showing the preserved distribution and plate tectonic reconstructions of the eight tectonostratigraphic basins and intervening volcanic and deformational episodes of North Greenland. A, Middle Proterozoic interior sag (Independence Fjord Basin), c. $1380 \mathrm{Ma}$; B, Middle Proterozoic rifting and volcanism (Midsommers $\emptyset$-Zig-Zag Dal volcanic event), c. 1230 $\mathrm{Ma}$; C, Late Proterozoic passive margin of the Iapetus Ocean (Hagen Fjord - Rivieradal Basin), 800-590 Ma; D, Latest Proterozoic - Early Palaeozoic passive margin (Franklinian Basin), 640(?)-380 Ma; E, Caledonian foreland basin, c. $410 \mathrm{Ma}$; F, Closure of the Franklinian Basin (Ellesmerian Orogeny) and formation of a foreland basin, c. 360 Ma; G, Late Palaeozoic rift basin, 360-260 Ma; H, Mesozoic oblique-slip basin, 250-80 Ma; I, Early Tertiary initiation of transform margin, 50-0 Ma. 


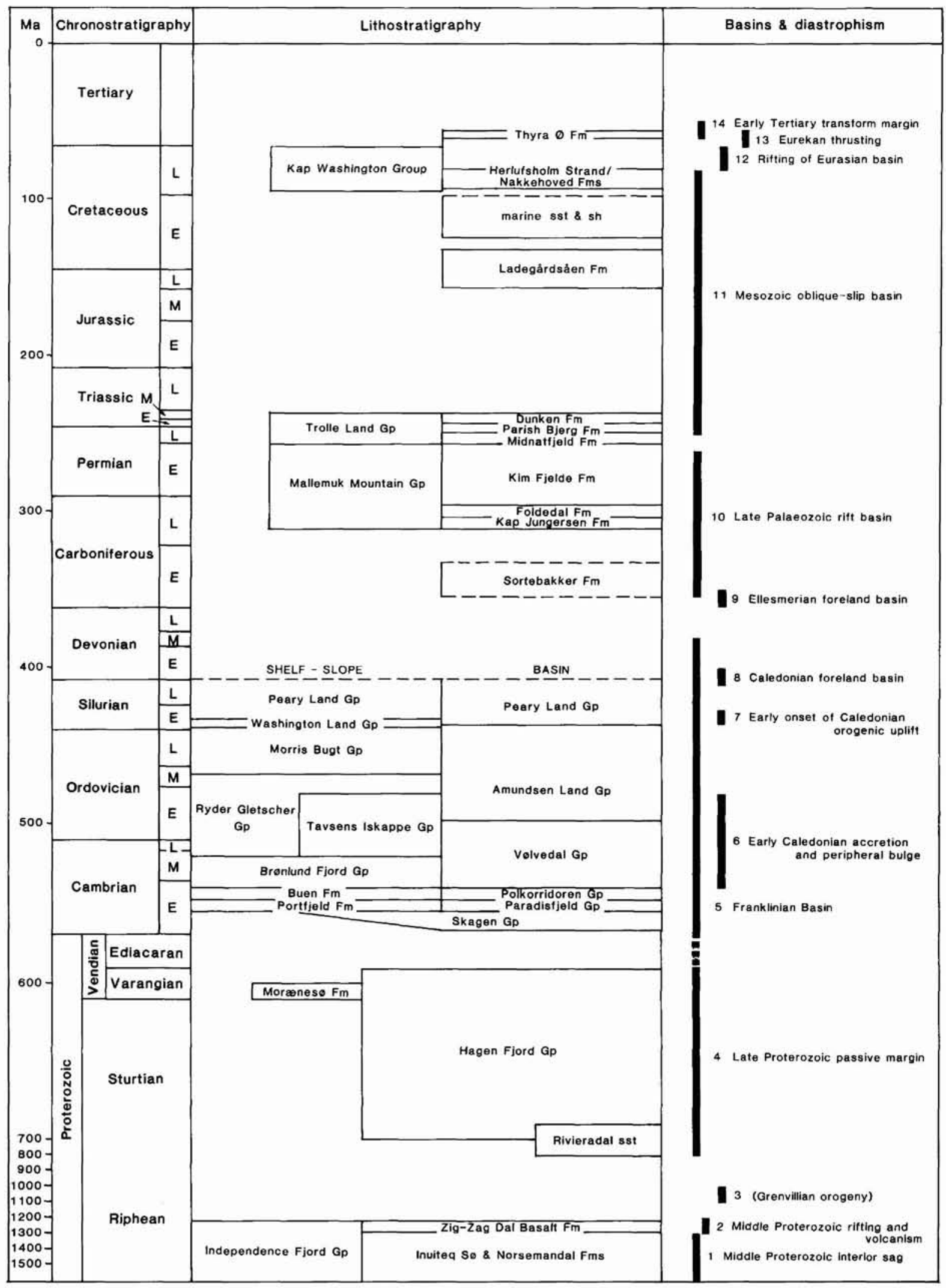

Fig. 4. Simplified stratigraphic scheme covering the Middle Proterozoic to Tertiary succession of North Greenland. Basins and periods of diastrophism as in Fig. 2. 


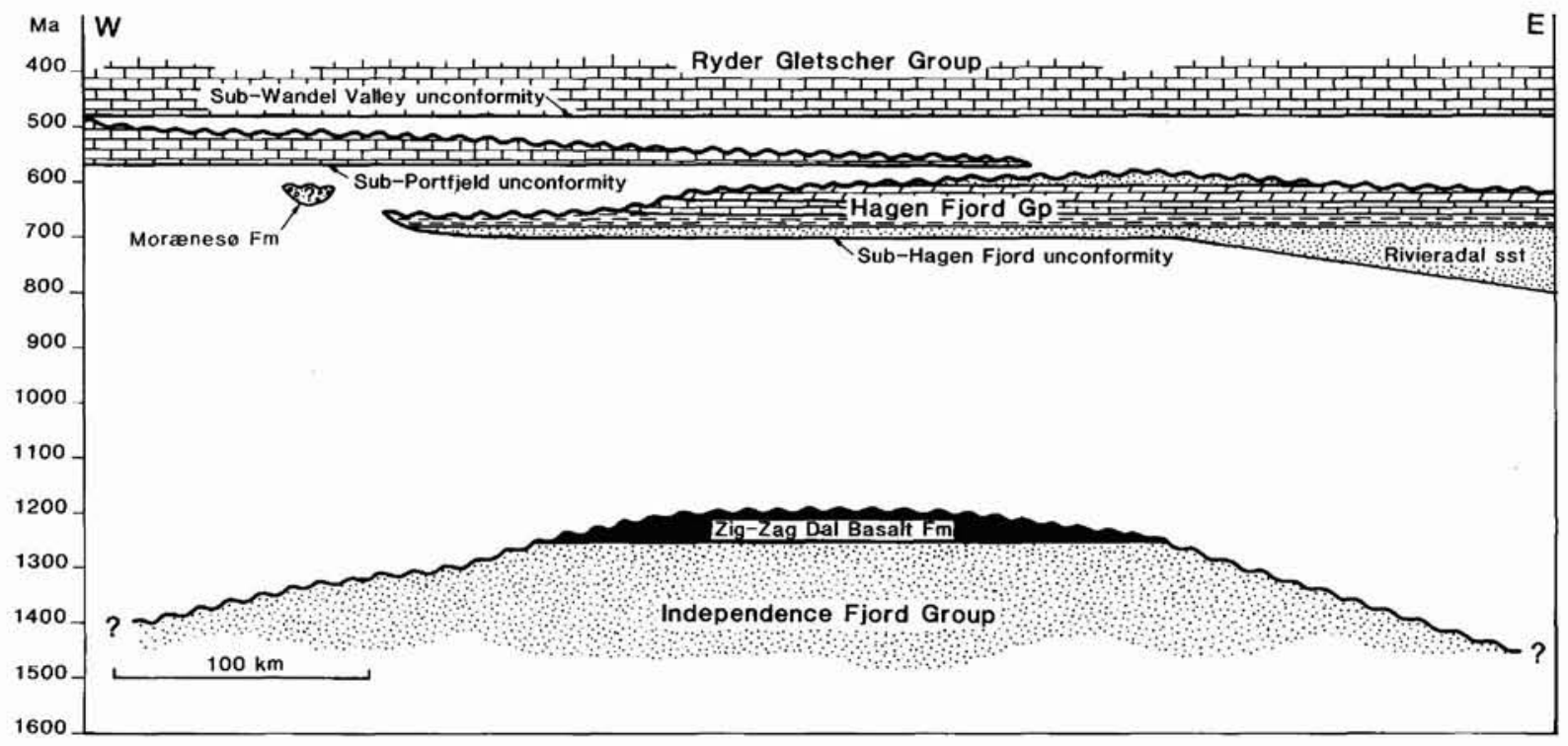

Fig. 5. Cross-section from Peary Land (west) to Kronprins Christian Land (east) showing sub-Hagen Fjord, sub-Portfjeld and sub-Wandel Valley unconformities (after Clemmensen \& Jepsen, in press).

represented by stromatolitic dolostones (Fyns $\$ \varnothing$ Formation). The presence of an outer platform slope is recorded by slump breccias and subtidal stromatolitic Conophyton mounds.

The demise of the platform coincided with the reappearance of glauconitic, tidally influenced shelf sandstones with Skolithos (Kap Holbæk Formation).

An approximately $2500 \mathrm{~m}$ thick deep-water succession of basinal turbidites and conglomerates referred to the Rivieradal sandstones occurs to the east in large Caledonian nappes in Kronprins Christian Land. The nappes were probably derived from the east or southeast and were transported westwards for at least 100150 km (Hurst \& McKerrow, 1981; Hurst et al., 1985).

Due to tectonic complexity, the sedimentary and stratigraphic relationships between the Hagen Fjord Group and the Rivieradal sandstones are not yet fully elucidated. However, a conformable shallowing upwards transition from the Rivieradal sandstones to the upper part of the Hagen Fjord Group (Campanuladal Formation and younger units) has been described from one of the nappes (Hurst \& McKerrow, 1981). The Rivieradal sandstones may thus be a deep-water correlative of the onlapping Jyske Ås Formation of the lower part of the Hagen Fjord Group, and this important occurrence, if correct, may document the genetic association of the two depositional systems.

The deep-water turbiditic facies and the shallowingupwards progradational nature of the combined Rivieradal - Hagen Fjord system suggests a syn-rift to early stage passive margin setting possibly related to the development of the Iapetus Ocean in areas currently east of present-day North Greenland.

Acritarchs from the upper part of the Rivieradal sandstones indicate a general Sturtian to Vendian age (c. 800-570 Ma). The top sandstones of the Hagen Fjord Group contain Skolithos suggesting an age not older than latest Proterozoic (late Vendian, Ediacaran).

A succession of glacially influenced deposits occur in southern Peary Land and southern Wulff Land. It is referred to the Morænesø Formation and is probably related to the Late Proterozoic (Varangian), glaciation known from Spitsbergen, East Greenland, Europe, Canada and U.S.A. The glacial event is poorly dated, however, and it may be of older Proterozoic age. The data do not allow any clear correlation between the Morænes $\varnothing$ Formation and the Hagen Fjord Group (Sønderholm \& Jepsen, 1991). Deposition took place in widely separated valleys and the unconformity at the base of the formation reflects a relief of at least $190 \mathrm{~m}$ (Collinson et al., 1989). The main facies are diamictites representing resedimented tills, and fluvial, aeolian and lacustrine sandstones and shales. However, only a single true till has been found. The glacigenic succession is topped by a thin, but spectacular stromatolitic dolostone with laterally linked domal stromatolites up to $2 \mathrm{~m}$ high and $8 \mathrm{~m}$ in cross section. This transgressive development possibly reflects a glacio-eustatic rise in sealevel. 


\section{5, Latest Proterozoic - Early Palaeozoic passive margin (Franklinian Basin), c. 640(?)-380 Ma}

The east-west trending Franklinian Basin was initiated by rifting probably in latest Proterozoic time (Figs $2,3 \mathrm{D}, 4)$. This is reflected by uplift, block-faulting and erosion of Late Proterozoic and older strata. The timing of the onset of rifting is poorly known. Trettin (1989) suggested that the Franklinian diabase swarm (c. 750 $\mathrm{Ma}$ ) and basic volcanics (635-640 Ma) in Arctic Canada represent the initial rifting. The oldest exposed Franklinian deposits are of Early Cambrian age, but may extend back into the latest Proterozoic.

The Franklinian sea transgressed the eroded surface from north to south, and more than $1 \mathrm{~km}$ of onlapping Lower Cambrian sediments were deposited. The hiatus between the oldest exposed Cambrian rocks and the Proterozoic Iapetus succession in eastern North Greenland is estimated to 10-30 Ma by Sønderholm \& Jepsen (1991).

The Franklinian Basin extends today westwards from easternmost North Greenland into Ellesmere Island and probably as far as Melville Island in the Canadian Arctic Islands (Trettin, 1989). A well defined syn-rift succession is not known, but the oldest exposed deposits show features suggestive of a late syn-rift or early postrift origin. Ocean floor volcanic rocks related to the opening of the Franklinian Basin have not been directly observed.

The Franklinian Basin is oriented roughly perpendicular to the western margin of the slightly older Iapetus Ocean, marked today by the front of the East Greenland Caledonides. It may thus represent an aulacogen which reached a narrow ocean stage (Surlyk, 1982; Surlyk \& Hurst, 1983, 1984). The aulacogen interpretation is supported by the dominantly ensialic nature of the Franklinian Basin. The marked Early Palaeozoic differentiation into a wide shallow marine shelf bordered by a deep-water basin suggests that a spreading centre was formed and a narrow ocean stage was reached, possibly already in Early Cambrian times.

A series of small volcanic centres occurs in Peary Land spatially related to the Harder Fjord Fault Zone (Fig. 1). Blocks in the pipes are intensely brecciated and comprise local sediments, fresh basement metamorphic rocks and associated igneous rocks, and a suite of highly altered basic volcanics, gabbros and serpentinites (Parsons, 1981). The alteration occurred prior to their incorporation in the pipes. A single whole rock $\mathrm{K} / \mathrm{Ar}$ age of $380 \pm 5 \mathrm{Ma}$ (Middle Devonian, Ellesmerian) has been obtained (Pedersen \& Holm, 1983). Parsons (1981) speculated that the spilite-serpentinite assemblage is an otherwise unexposed, marginal, ocean-floor assemblage, and this is supported by the occurrence of abundant volcanic fragments in a nearby Cambrian Vølvedal Group conglomerate. This scenario is followed here, and it is suggested that the preserved mainly ensialic part of the Franklinian continental margin had reached a state of extension where submarine volcanicity accompanied turbidite deposition in the vicinity of an old deep-seated basin margin fault revived much later as the Harder Fjord Fault Zone.

The southern margin of the Franklinian Basin is well exposed across North Greenland, whereas the original northern margin is not preserved due to later compressive deformations, strike-slip faulting and plate separations.

The exposed succession shows a clear distinction between a southern shelf and a northern deep-water basin with an intervening slope. The boundary between the basin and shelf is strongly disturbed by Ellesmerian and later tectonism in most areas.

The shelf-slope-basin formed linked depositional systems during Cambrian-Ordovician times, whereas independent shelf and basin systems were developed in the Silurian (Surlyk et al., 1980). Nine depositional stages were recognised in the evolution of the deep-water basin (Surlyk \& Hurst, 1983, 1984). Soper \& Higgins (1987) suggested that a re-grouping into three phases of the nine basinal stages was more meaningful in terms of geotectonic control. This represents a mixing of the depositional systems concept with the concept of synrift and thermal subsidence phases of the simple stretching model of McKenzie (1978). Their suggestion of the first three stages of Surlyk \& Hurst $(1983,1984)$ as representing the syn-rift prism is not followed here. Franklinian syn-rift deposits have not been identified with certainty, and the bulk of the first three stages undoubtedly represents a fairly late stage in passive margin evolution where clear differentiation into a broad shelf, a slope and a deep-water basin had taken place.

The boundary between these three main sedimentary regimes progressed towards the craton in several steps (Surlyk et al., 1980; Surlyk \& Hurst, 1983, 1984). The deep-water basin thus expanded southwards by foundering of the outer shelf-upper slope along east-west lineaments which may represent deep-seated normal faults or flexures. This pattern of evolution has now also been recognised in the Canadian Arctic Islands (Trettin, 1987, 1989).

Despite earlier objections (Higgins et al., 1981; Higgins, 1986; Soper \& Higgins, 1987), the concept of a structurally controlled back-stepping shelf margin is now widely accepted (cf. Soper \& Higgins, 1990). Basement faulting is considered to have controlled the rough posi- 
A. EARLY CAMBRIAN

Late Skagen - early Portfjeld/Paradisfjeld time

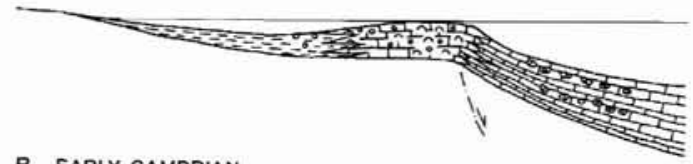

B. EARLY CAMBRIAN

Buen - Polkorridoren time

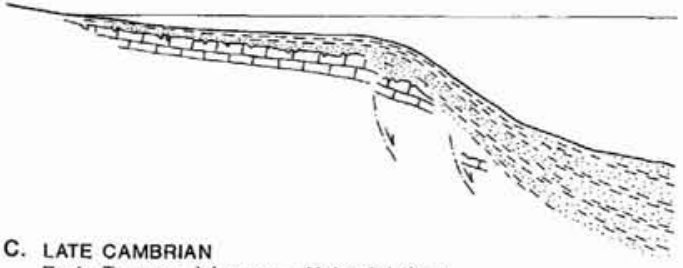

Early Tavsens Iskappe - Volvedal time

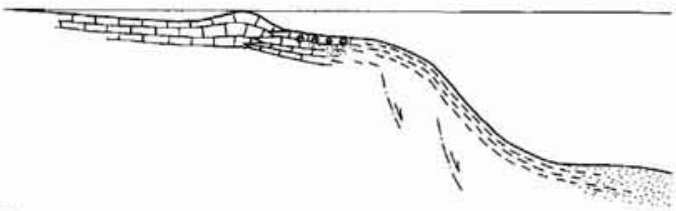

D. LATE CAMBRIAN - EARLY ORDOVICIAN

Late Tavsens Iskappe - Amundsen Land time

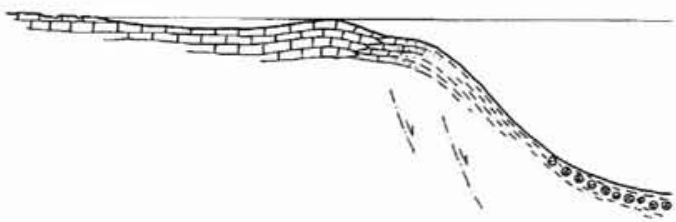

E. MIDDLE ORDOVICIAN

Late Wandel Valley - late Amundsen Land time

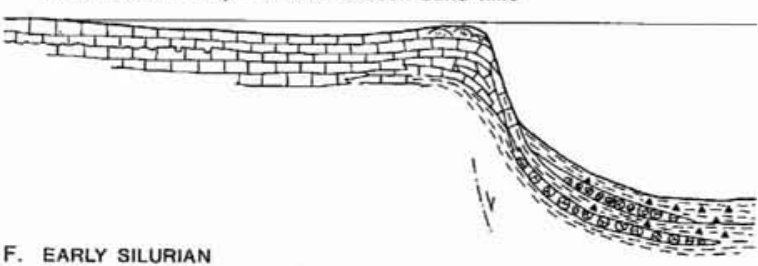

Samuelsen Høj - Merqujôa time

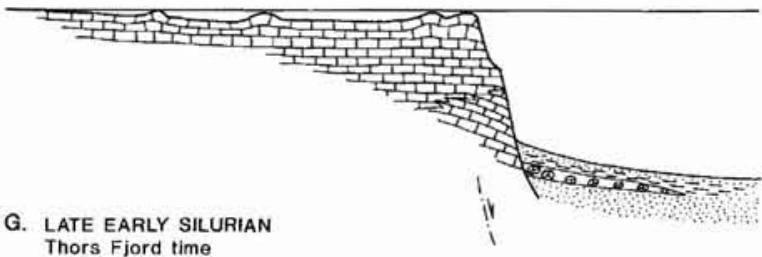

Thors Fjord time

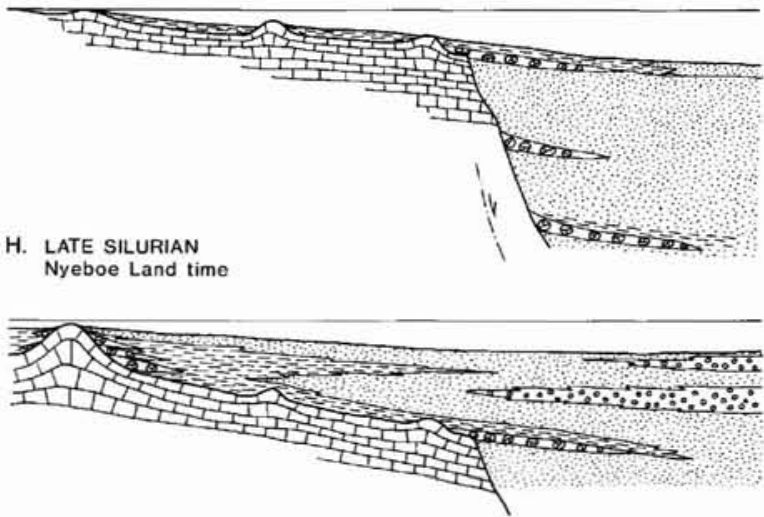

Fig. 6. Simplified south-north cross-sections of the Franklinian Basin (not to scale). A, Late Skagen - early Portfjeld/Paradisfjeld time (Early Cambrian); B, Buen - Polkorridoren time (Early Cambrian); C, Early Tavsens Iskappe - Vølvedal time (Late Cambrian); D, Late Tavsens Iskappe - Amundsen Land time (Late Cambrian - Early Ordovician); E, Late Wandel Valley - late Amundsen Land time (Middle Ordovician); F, Samuelsen Høj-Merqujôq time (Early Silurian); G, Thors Fjord time (late Early Silurian); H, Nyboe Land time (Late Silurian).

tion and configuration of the shelf-slope transition, but the boundary itself was not necessarily an actual fault or a faulted scarp.

The oldest known sediments of the Franklinian Basin belong to the Skagen Group of presumed Early Cambrian age (Figs 4, 6). The group was first recognised in the fold belt in Peary Land as a strongly deformed succession of sandstones and mudstones, at least $500 \mathrm{~m}$ thick. The depositional environment is not known. Stratigraphically equivalent, well preserved, strata occur in western North Greenland (Wulff Land) and have been studied in more detail (Surlyk \& Ineson, 1987a). The unit is here at least $500-600 \mathrm{~m}$ thick but the base of the group is not seen. The thickness may be much greater as the correlative Kennedy Channel Formation in Ellesmere Island has a maximum exposed thickness of c. $1200 \mathrm{~m}$ (Long, 1989a).

Skagen Group sediments are of marine shelf origin and a number of siliciclastic, carbonate, and mixed facies occur. Deposition took place on a storm-dominated shelf and on shallow water carbonate shoals. The unit thus records the initial differentiation of the shelf into a carbonate platform and a mainly siliciclastic storm-influenced shelf (Fig. 6).

The Skagen Group as seen in Wulff Land wedges out to the south over a few tens of kilometres and is overstepped by the overlying Portfjeld Formation, which rests directly on crystalline basement or the Proterozoic Morænes $\emptyset$ Formation in southern Wulff Land (Fig. 5). The basin configuration during Skagen - Kennedy 
Channel times is not known. There is no direct evidence for rifting such as fault-scarps, tilted fault-blocks or syn-rift conglomerates. A late syn-rift or early post-rift origin is possible and is supported by the apparent lack of differentiation into shelf, slope and basin. The occurrence of coarse pebbly sandstones, and the cratonwards overstep and onlap by the overlying Portfjeld Formation also lend credence to this interpretation.

The predominantly siliciclastic deposits of the Skagen Group gradually gave way to platform carbonates of the Portfjeld Formation which pass northwards into slopeto-incipient basin carbonate mudstones and conglomerates of the Paradisfjeld Group.

The Portfjeld Formation thickens appreciably from a few hundred metres to as much as $700 \mathrm{~m}$ from south to north, suggesting the development of a northern, rapidly accreting high-energy platform rim. Carbonate deposition in this area was probably initiated when the inner shelf still received terrigenous sand and mud (Fig. 6).

The Paradisfjeld Group is at least $1 \mathrm{~km}$ thick and displays features characteristic of both shelf and slope or basinal environments. Hummocky cross-stratified units occur in eastern Peary Land while calcarenitic turbidites and carbonate debrites are common especially in the upper part of the unit.

The nature of the shelf-to-basin transition is not known due to strong deformation. A tectonic control of the shelf margin has been suggested, and may have coincided with a precursor to the present-day Harder Fjord Fault Zone in Peary Land (Surlyk \& Hurst, 1984; Soper \& Higgins, 1987; Fig. 1). Huge olistoliths derived from the Portfjeld Formation occur in the lower part of the turbiditic Polkorridoren Group which overlies the Paradisfjeld carbonates. This suggests that the Portfjeld platform margin was developed as a steep escarpment, parts of which persisted or were revived by later faulting in Polkorridoren times.

The Portfjeld-Paradisfjeld system was terminated by a major fall in sea-level. The top of the Portfjeld platform was eroded, stained red and brecciated in many areas. The top of the deeper water Paradisfjeld succession in contrast passes into the siliciclastic Polkorridoren Group without any recognised break in sedimentation (Figs 4,6). The strongest effects of the sea-level fall are seen along the southern outcrop margin. A remarkable mega-breccia, $85-270 \mathrm{~m}$ thick, was formed by collapse, break-up and mass-transport of the entire Portfjeld Formation (Surlyk \& Ineson, 1987a). The megabreccia rests upon crystalline basement or thin remnants of the Proterozoic Morænesø Formation and consists of blocks and large slabs of Portfjeld carbonate, quartzite, gneiss, and red siltstone set in a matrix of carbonate and quartz sand. The mega-breccia was probably formed after a period of karstification during an interval of major sea-level drawdown. Subsequent collapse and basinwards mass movement was possibly triggered by earthquakes along the southern basin hinge line or along the platform margin scarp. The basinal equivalent is possibly represented by limestone conglomerate debrites which occur in the top part of the Paradisfjeld Group in a broad belt over a length of $250 \mathrm{~km}$ along the southern outcrop margin of this unit.

It may be speculated that the unconformity topping the Portfjeld Formation was caused by a late rift peripheral bulge migrating southwards and that it is analogous to the so-called breakup unconformity (cf. Falvey \& Middleton, 1981; Long 1989b). The marked seawards thickening of the sedimentary prism and the beginning of differentiation into shelf, slope and basin environments may alternatively suggest that the Portfjeld-Paradisfjeld system represents an early passive margin succession formed after the onset of sea-floor spreading.

The sea-level fall resulting in the demise of the Portfjeld platform was followed by a major sea-level rise, and a siliciclastic mud-dominated shelf sea transgressed the karstified surface of the carbonate platform (Fig. 6). This shift in facies was accompanied by a marked seawards increase in subsidence, and by a cratonwards shift in the shelf-slope boundary, possibly caused by flexural downbending of the outer shelf (Surlyk \& Hurst, 1984).

The shelf mudstones and tidally influenced inner shelf sandstones referred to the Buen Formation are 425-500 $\mathrm{m}$ thick over most of the shelf, but thin to $250 \mathrm{~m}$ along the shelf-slope break (Higgins et al., 1991). This change is probably due to mass wasting and sediment bypassing in the slope region and does not reflect a local decrease in subsidence. The succession thickens rapidly in the mid and lower slope regions and correlative deposits reach thicknesses of 2-3 km in the basin.

The basinal deposits are referred to the Polkorridoren Group and consist of alternating packages of variegated mudstones and thick-bedded sandy turbidites, $100-500 \mathrm{~m}$ thick, showing transport directions towards west, north and, less commonly east. They were deposited on relatively small sand-rich submarine fans which were deflected mainly westwards along the basin axis. Carbonate conglomerates also occur and a particularly spectacular level is situated $600 \mathrm{~m}$ above the base of the group. It is traceable over $120 \mathrm{~km}$ along strike, and the clasts range in size from cobbles to $300 \mathrm{~m}$ long blocks, mainly derived from the Portfjeld Formation. This indicates that parts of the Portfjeld platform margin escarpment were exposed to erosion and spalling of joint blocks also in early Buen - Polkorridoren times. The Polkorridoren Group is topped by the widespread, up 
to $400 \mathrm{~m}$ thick variegated Frigg Fjord mudstone, reflecting progressive abandonment of the submarine fans, probably caused by a major sea-level rise.

\section{6, Early Caledonian accretionary event and formation of peripheral bulge, $c$. 540-480 Ma}

Starvation of the Polkorridoren fans reached a climax in the late Early Cambrian. From then on through Ordovician times the Franklinian passive margin was characterised by the development of a thick carbonate platform and a sediment starved black shale and chert basin (Figs 4, 6). This pattern was modified, however, by progressive shelf uplift in eastern North Greenland terminating in the Early Ordovician (Fig. 7). The western Franklinian shelf beyond the influence of the uplift is represented by a thick and varied succession of carbonates mainly of restricted platform aspect with subordinate siliciclastic sediments and evaporites, which together form the up to $1500 \mathrm{~m}$ thick Ryder Gletscher Group. In the earliest Ordovician carbonate deposition was interrupted by a siliciclastic interlude of the Permin Land Formation, reflecting maximum uplift and erosion in eastern North Greenland coupled with eustatic lowstand (Bryant \& Smith, 1990).

The progressive late Early Cambrian - earliest Ordovician uplift of the eastern shelf is reflected by the complex facies relationship exhibited by the Brønlund Fjord and Tavsens Iskappe Groups (Fig. 4).

The basinal succession off the eastern uplifted shelf is thickly developed. It forms the $600-700 \mathrm{~m}$ thick Vølvedal Group, which in addition to the essentially condensed deposits of dark cherts and shales contains quartzose turbidite units and carbonate conglomerates (Figs 4, 6). The resedimented deposits were derived from the southern platform and formed one or more relatively small borderland fans. It is significant that the onset of fan deposition was contemporaneous with the siliciclastic Permin Land event on the shelf.

Subsequent to the Permin Land event uniform carbonate platform deposition was resumed all along the Franklinian shelf. The uplifted and eroded platform in eastern and central North Greenland was submerged and a major unconformity was formed below the late Early - Middle Ordovician Wandel Valley Formation (Fig. 7).

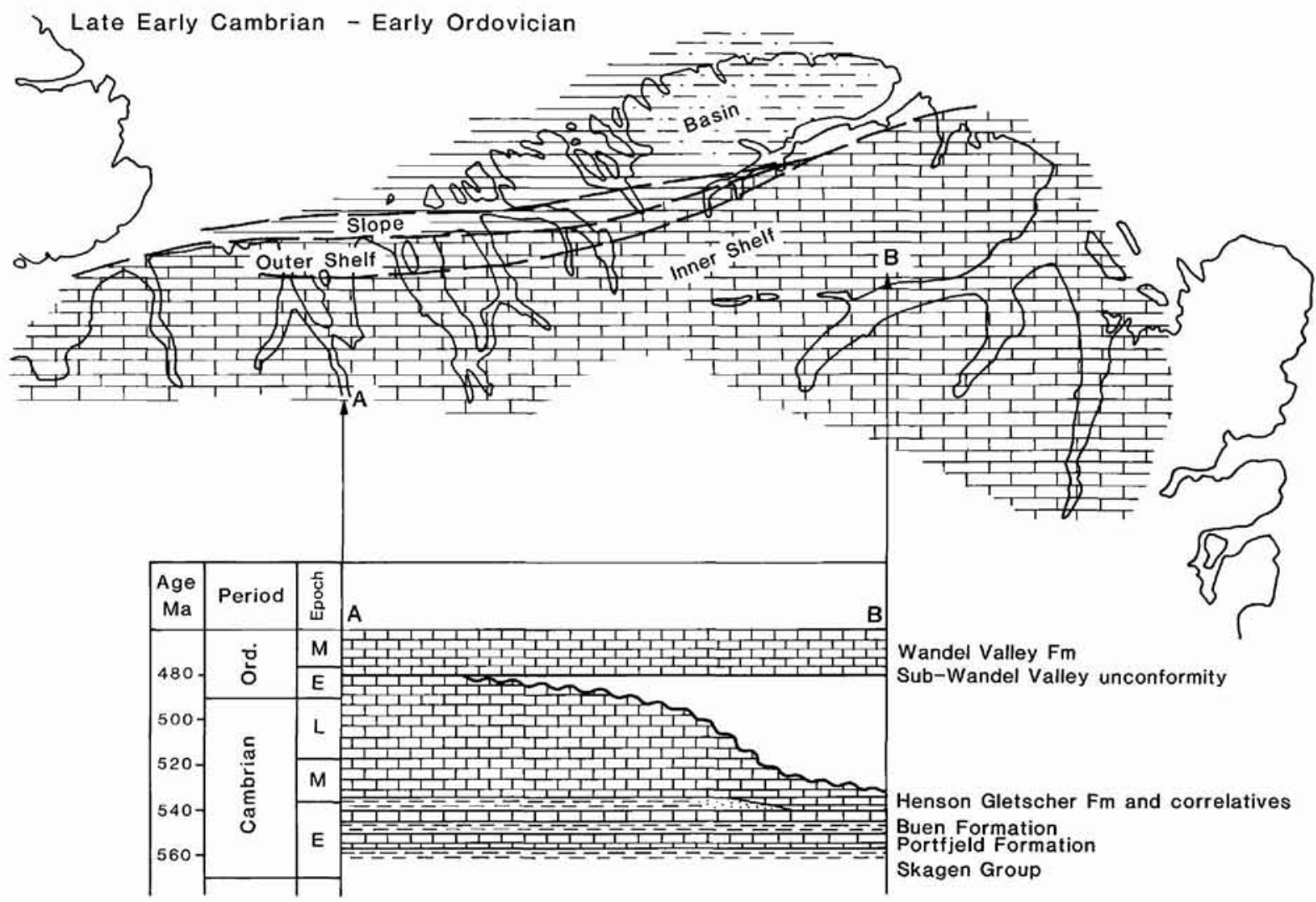

Fig. 7. Stratigraphic east-west cross-section of the Franklinian shelf showing the sub-Wandel Valley unconformity. 
Late Proțerozoic
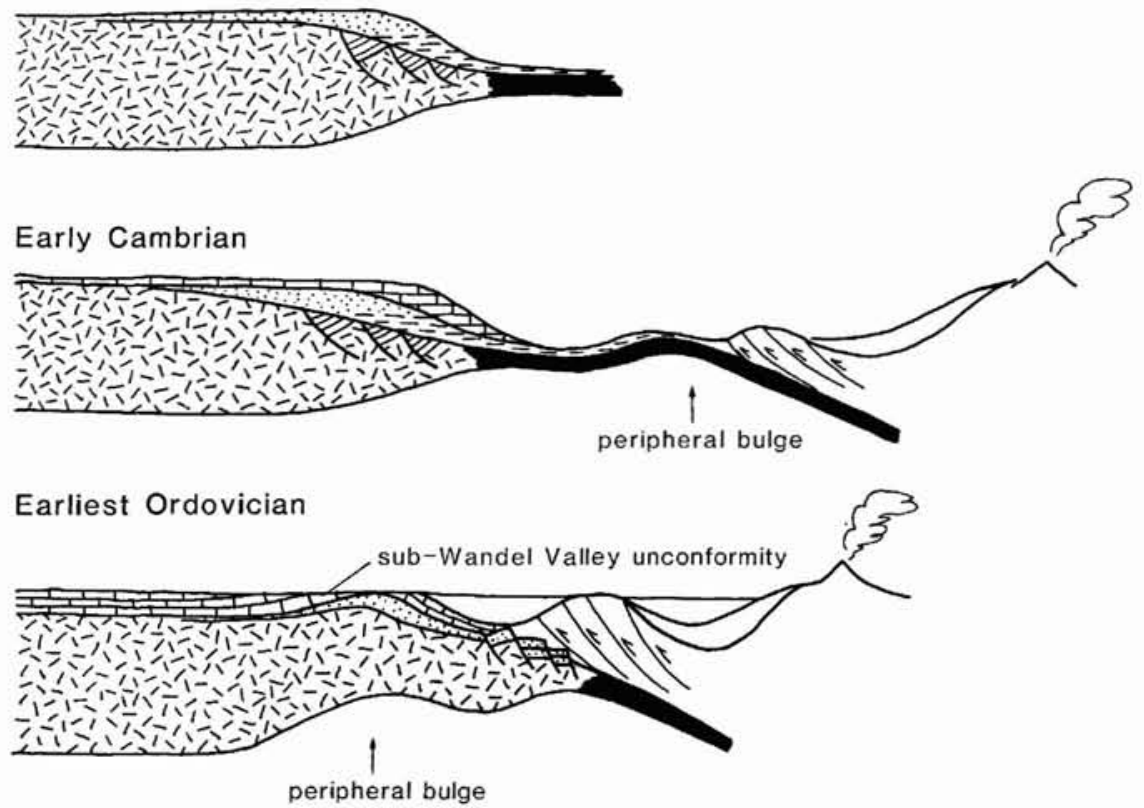

Fig. 8. Schematic diagram showing formation of a westwards migrating peripheral bulge during an early Caledonian collisional event along the western margin of the Iapetus Ocean. Bulge uplift and erosion were responsible for the formation of the subWandel Valley unconformity (Fig. 7).

Middle Ordovician

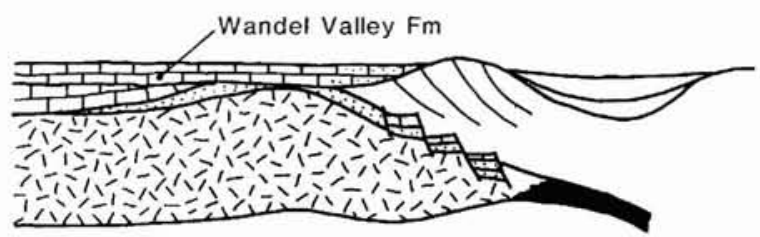

The underlying control of uplift and erosion is interpreted as a reflection of westwards migration of a peripheral bulge during an early collisional event along the western margin of the Iapetus Ocean in Middle Cambrian - earliest Ordovician times (Figs 7, 8; Surlyk \& Hurst, 1984). This is the first in a series of Caledonian events influencing the evolution of the Franklinian passive margin.

It is significant that the Caledonian bulge uplift of the eastern Franklinian shelf (Surlyk \& Hurst, 1984) coincided in time with the M'Clintock Orogeny of Ellesmere Island, the Taconic Orogeny of Newfoundland, ophiolite obduction and uplift in western Norway, and preCaradocian deformation in central western Spitsbergen (Thon, 1985; Trettin, 1987; Williams \& Hatcher, 1983). The Early Ordovician unconformity of the eastern Franklinian shelf provides an important link in constraining the timing of amalgamation of the first in a series of successively accreting slices of Pearya - the composite terrane forming the northernmost part of Ellesmere Island (Trettin, 1987).

It is suggested here that collision of a microplate of Spitsbergen affinity with the eastern margin of the
Franklinian Basin was initiated in Middle Cambrian times. The southern part of this plate was firmly welded to eastern North Greenland in the earliest Ordovician. After this event regular subsidence was resumed throughout the Franklinian passive margin.

A fault slice of the northern part of the microplate possibly slid westwards along a major E-W trending strike-slip fault situated in the northern part of the Franklinian deep-water basin. This slice was accreted to northern Ellesmere Island during the early Middle Ordovician M'Clintock Orogeny (cf. Trettin, 1987).

The stable, uniformly subsiding period that succeeded the long period of progressive shelf uplift to the east was characterised by platform margin backstepping, aggradation and development of a steep, precipitous slope, the Navarana Fjord Escarpment (Fig. 6). North of the escarpment a broad sediment-starved bypass slope formed, whereas the rate of deposition was higher in the basin floor environment. Stable platform aggradation commenced with the late Middle Ordovician sea-level rise and persisted into the Early to Middle Llandovery (Early Silurian).

A pronounced shallowing followed by marked dee 
pening occurred, however, in latest Ordovician - earliest Silurian times. These fluctuations in relative sealevel may be of true eustatic nature related to the late Ordovician glaciations.

In the deep-water basin the small borderland fans of the Vølvedal Group were abandoned and a long period of sediment starvation and, at times, also stagnation was initiated in the basin floor and slope regions. The deposits of this phase are referred to the Amundsen Land Group and include chert, cherty shale, black limestone, and dolomitic mudstone.

The eastern part of the basin received in addition thick carbonate conglomerates of the up to $200 \mathrm{~m}$ thick Kap Mjølner Formation. These Early Ordovician debris sheet units can be traced over wide areas of Johannes V. Jensen Land but become less important westwards and northwards. They were derived from unroofing of the pre-Wandel Valley peripheral bulge of the eastern shelf.

Conglomerate deposition faded out in middle Ordovician times in conjunction with termination of uplift and the development of an aggrading, gradually subsiding shelf, and slow sedimentation of fine-grained deposits was resumed throughout the basin. Towards the end of this stage in the Late Ordovician - Early Llandovery, the incoming of thin-bedded silty turbidites heralded an important event in the evolution of the basin. Starved basin deposition of the Amundsen Land Group came to an end, and turbidite sedimentation of the very thick sand-rich Peary Land Group commenced abruptly in the Llandovery (Fig. 4).

\section{7, Early onset of Caledonian orogenic uplift: c. 435 Ma}

At the beginning of fan building of the Peary Land Group the platform margin was formed by the $1300 \mathrm{~m}$ high Navarana Fjord Escarpment dipping up to $45^{\circ}$. The basin became rapidly filled with sandy turbidites which onlapped the scarp towards the south (Fig. 6). The outer shelf was gradually down-flexed due to loading by fan turbidites with their source in the rising Caledonian mountain belt to the east (Surlyk, 1982; Higgins et al., 1991). The evolution of the carbonate platform during this time interval thus reflects normal passive margin processes upon which were superimposed the far reaching effects of Caledonian mountain building.

The early Late Llandovery flexural down-bending of the outer shelf can be traced all across North Greenland. The initial phases are recorded by deposition of relatively deep-water, low-energy carbonates. In the southern inner platform contemporaneous deposits include biostromal units formed in extensive high-energy shoals.
The progressive drowning of the outer platform was accompanied by retreat of the shelf margin to a more southerly position, and the developement of a reef belt $850 \mathrm{~km}$ long and up to $100 \mathrm{~km}$ wide (Fig. 6). The reefs, however, did not form a complete barrier across the region and a steep indented shelf margin developed. An essentially flat carbonate platform was maintained between and behind the mounds (Sønderholm \& Harland, 1989). Continued subsidence and associated sea-level rise ultimately resulted in complete drowning of the platform and inundation by deep-water muds during latest Llandovery to earliest Wenlock time. Carbonate deposition was only maintained in some of the larger buildups, and a few of these appear to have continued at least to the end of the Silurian.

The huge deep-sea fan of the Peary Land Group possibly represents the world's largest ancient deep-sea fan (Hurst \& Surlyk, 1982; Surlyk, 1982; Surlyk \& Hurst, 1984). It developed extremely rapidly in the Late Llandovery after the start of fine-grained turbidite deposition in Peary Land close to the Ordovician-Silurian boundary. The Peary Land fan extended from the eastern end of the Franklinian Basin far into the Canadian Arctic Islands. The provenance area was the rising Caledonian mountain belt, and the main source of the huge thickness of quartzose turbidites was undoubtedly the thick successions of Proterozoic sandstones exposed in central and eastern North Greenland, and their correlatives.

The fan system was elongate, parallel to the Franklinian platform margin. The length was $1500-2000 \mathrm{~km}$ if its down-current extension in the Canadian Arctic Islands is included. The original width is not known, because the northern margin is not preserved, but it was more than $200 \mathrm{~km}$. The maximum preserved thickness is about $5 \mathrm{~km}$. The total fan volume is thus considerably more than 2 million $\mathrm{km}^{3}$.

During the first stage of fan development the southern margin was formed by the Navarana Fjord Escarpment. The bulk of this first phase of fan deposits is referred to the Merqujôq Formation. Turbidite deposition was punctuated by several episodes of carbonate conglomerate deposition from the outer platform and marginal escarpment (Hurst \& Surlyk, 1982; Surlyk \& Ineson, 1987a, b).

The turbidites had filled the basin to the edge of the platform in the latest Llandovery, when the shelf foundered and was inundated by black mudstones and siltstone turbidites of the Thors Fjord Member (Figs 4, 6). This fine-grained unit covered the northern outer shelf in the Late Llandovery, and reached the southern inner part somewhat later, at the Llandovery-Wenlock boundary. It extends unchanged from the platform, 
across the escarpment and further basinwards over the turbidites of the Merqujôq Formation.

Hurst et al. (1983) suggested that loading of the eastern shelf by Caledonian nappes was a direct cause of the latest Llandovery foundering of the Franklinian carbonate platform. This interpretation is not followed here: the drowning of the platform was an integrated event which affected the entire Franklinian shelf not just the eastern part adjacent to the Caledonian nappes. The drowning event is represented by the mudstones of the Thors Fjord Member which drape both the platform carbonates and the sandy turbidite succession of the Merqujôq Formation. This means that platform drowning was associated with fan starvation and near abandonment, which is the opposite effect to that which would be expected according to the nappe loading hypothesis. Furthermore, the youngest turbidites preserved in the nappes in eastern North Greenland are of middle Wenlock age. This indicates that deep-water turbiditic environments still existed in the areas east of Kronprins Christian Land at a significantly later time than the Late Llandovery foundering of the platform. This excludes loading by nappes transported from the east as a cause for the foundering. The foundering of $30000-40000 \mathrm{~km}^{2}$ of carbonate shelf in North Greenland is here ascribed to the combined effects of progressive flexural down-bending of the outer shelf due to loading of the Franklinian deep-water basin by the Peary Land turbidites, and a major eustatic sea-level rise, which has been demonstrated for other parts of the world by Johnson et al. (1985).

Following this phase of basin expansion the Peary Land fan rapidly built up again and now reached its greatest dimensions. A change in nature of the Caledonian provenance terrain is reflected by the influx of chert pebble turbidites in Middle Wenlock times. These were probably derived from Ordovician cherts correlative with the basinal Amundsen Land Group which were uplifted and eroded in the Caledonian mountains. The pebbly system is up to $600 \mathrm{~m}$ thick and reached the western parts of the basin in early Ludlow times.

The last phase of basin filling is only known from western North Greenland. It is of latest Silurian age, up to $1000 \mathrm{~m}$ thick and includes mainly fine-grained thinbedded turbidites, contourites and mudstones (Fig. 6).

The Franklinian Basin thus records more than 150 million years of passive margin evolution. The syn-rift succession is not exposed, and the oldest rocks probably represent the latest syn-rift to early post-rift stage in basin evolution (Fig. 3).

\section{8, Caledonian foreland basin, c. $410 \mathrm{Ma}$}

Closure of the Iapetus Ocean during the Caledonian orogeny was accompanied in north-eastern Greenland by westerly migration of thrust sheets or nappes (Fig. $3 \mathrm{E})$.

The nappes originated from east of the present-day coast-line of eastern North Greenland and North-East Greenland and travelled westwards for at least $100 \mathrm{~km}$. The thickness of the total nappe pile can be estimated to be about $5 \mathrm{~km}$ (Hurst et al., 1983). Loading by the nappes must have caused flexural down-bending of the eastern Franklinian shelf resulting in the formation of a roughly N-S trending foreland basin, parallel to the Caledonian front. The Caledonian nappe front was probably situated close to the east coast of MyliusErichsen Land in Danmark Fjord (Hurst et al., 1983).

The axial part of the E-W trending Franklinian Basin probably received some of the material derived from erosion of the thrust-belt, whereas some material must have accumulated in the foreland basin. The latter is not preserved due to later uplift and erosion. Its former presence is revealed, however, by the pronounced southwards extension of the low metamorphic zone in central and eastern North Greenland (Fig. 9; fig. 48 of Christiansen, 1989). This probably indicates that a wide $\mathrm{N}$-S oriented belt situated west of the Caledonian front was at one time covered by a thick succession of postFranklinian sediments. The foreland basin was probably c. $200 \mathrm{~km}$ wide and the distal part of the basin was located roughly at the head of Independence Fjord (Figs 1, 3).

\section{9, Closure of the Franklinian Basin (Ellesmerian Orogeny) and formation of a foreland basin, c. $360 \mathrm{Ma}$}

The youngest preserved Franklinian deposits are of latest Silurian - earliest Devonian age (Fig. 4). Closure of the Franklinian Basin took place in Middle or Late Devonian - Early Carboniferous times during the Ellesmerian Orogeny, when the North Greenland fold belt was formed (Fig. 3F). The orogeny is poorly dated and a clear separation between Caledonian, Ellesmerian and Tertiary (Eurekan) structures has not yet been made (Soper \& Higgins, in press a).

There is no evidence in North Greenland for an opposing plate which caused the Ellesmerian Orogeny by relative N-S convergence with its Greenland couterpart. The orogeny corresponds to the closure of the Franklinian Basin by $\mathrm{N}-\mathrm{S}$ compression. It affected the entire belt from eastern North Greenland to Prince Patrick Island in Arctic Canada and created a more than $375 \mathrm{~km}$ 

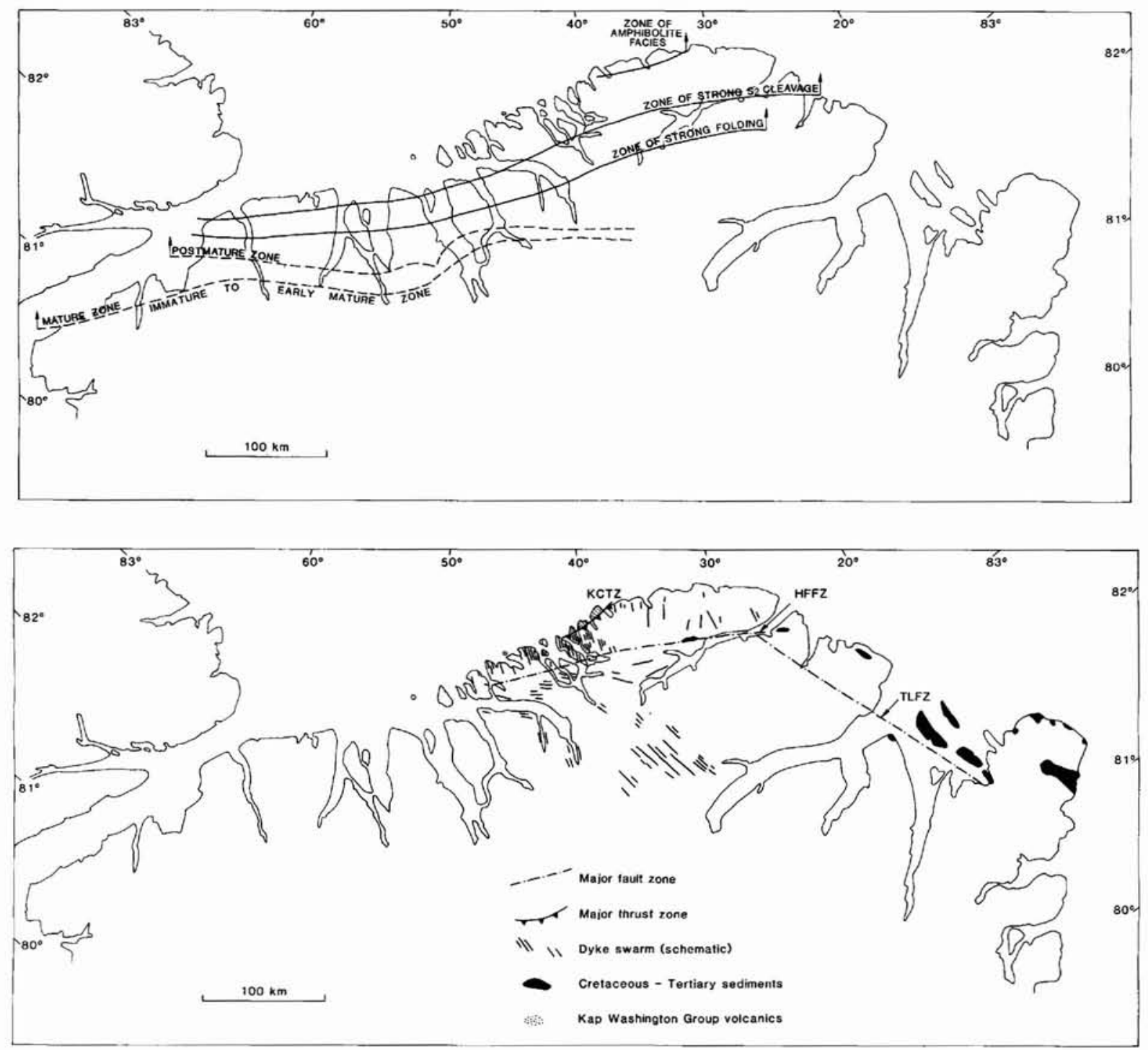

wide fold belt assemblage (see Trettin, 1989). In Canada the age of the orogeny is Middle or Late Devonian Early Carboniferous and it is assumed that this is also the case of the North Greenland fold belt. In the northern 'orthotectonic' part of the fold belt in North Greenland, polyphase north-vergent structures are developed in low amphibolite facies metasediments, and both the deformation and metamorphism decrease southwards. Along the southern margin of the fold belt approaching the foreland, structures verge south and take the form of a thin-skinned fold and thrust zone in which the basinal sediments were compressed against the Ordovician - Lower Silurian platform margin, the Navarana Fjord Escarpment. In western and central North Green- land the Navarana Fjord Escarpment is oriented almost east-west perpendicular to the stress direction, but it approaches a more north-easterly direction in Peary Land. Traced westwards across central North Greenland, the Ellesmerian margin changes character to become a major mountain front monocline which attains a maximum amplitude of about $7 \mathrm{~km}$. Soper \& Higgins (1990) suggested that the crystalline basement was involved in the formation of the monocline. They modelled the deep structure of the monocline as a Franklinian extensional basement ramp which was reactivated during the Ellesmerian Orogeny. After locking of the structure, shortening continued by development of thinskinned thrusts on the upper limb of the monocline. 

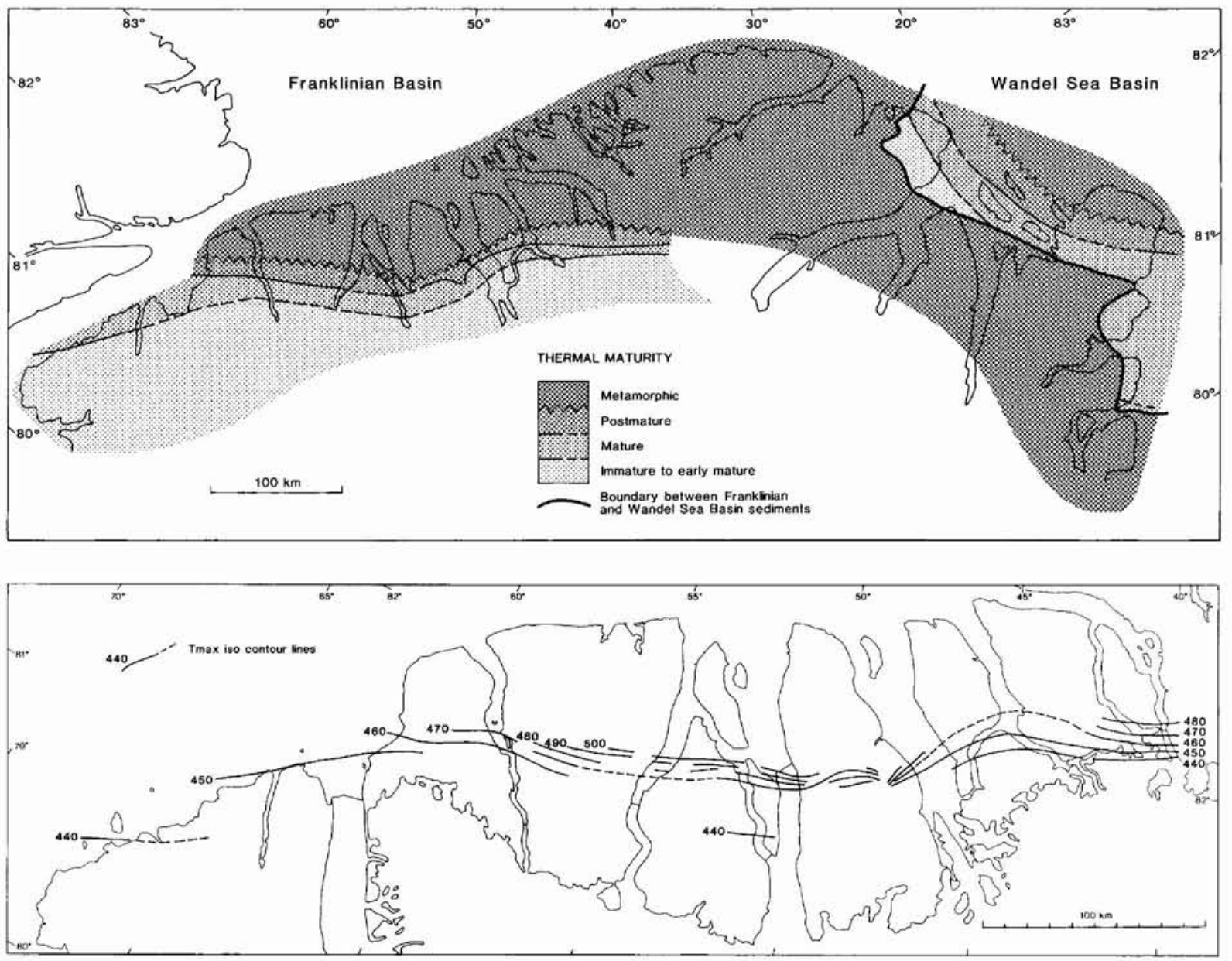

Fig. 9 A, Map of Ellesmerian tectono-metamorphic zones. From Christiansen (1989), modified after Dawes (1976) and Higgins et al. (1982, 1985); B, Map showing Cretaceous-Tertiary magmatic and tectonic features. After Christiansen (1989, fig. 61). For abbreviations, see Fig. 1; C, Map showing thermal maturity at the present-day surface. Modified from Christiansen (1989); D, Maturity map of central and western North Greenland showing $\mathrm{T}_{\max }$ iso-contour lines. Modified from Christiansen (1989).

A remarkable thrust-fault zone occurs in Peary Land and was termed the Vølvedal Orogeny by Pedersen (1986). It is limited to the north from the main North Greenland fold belt by the E-W trending Harder Fjord Fault Zone (Fig. 1). According to Pedersen (1986) the main tectonic transport direction was to the west with refraction toward south-west along the buried Lower Silurian platform margin formed by the Navarana Fjord Escarpment. It was interpreted as a foreland deformation related to the Caledonian mobile belt, which involved gravity gliding from a former existing northward extension of the East Greenland Caledonides (Håkansson \& Pedersen, 1982).

Surlyk \& Hurst (1984) alternatively suggested that the thrust faulting was caused by sinistral up-to-north oblique-slip transpression on the Harder Fjord Fault Zone. This interpretation explains the absence of the thrust belt in the relatively uplifted areas north of the fault zone. Both hypotheses thus consider the Vølvedal Orogeny as part of the Caledonian succession of sinistral transport events along an E-W trending mega-shear situated at the northern margin of the Franklinian Ba$\sin$.

It is possible that the Vølvedal Orogeny of Håkansson \& Pedersen (1982) is nothing but a local variation in the Ellesmerian frontal thrust zone formed by bending of the south-verging thrusts along the buried Navarana Fjord Escarpment (Soper \& Higgins, 1985; A. K. Hig- 
gins, personal communication, 1990). If this interpretation is correct the concept of a separate Vølvedal Orogeny is redundant.

The Ellesmerian Orogeny was in all probability accompanied by the formation of an E-W striking foreland basin caused by loading of the crust of southwards migrating thrust-sheets (Fig. 3). The moat-like basin was probably rather wide due to the mechanical strength of the old Archaean crust underlying the southern Franklinian shelf.

Later uplift in North Greenland has caused erosional removal of all direct evidence of the foreland basin deposits. In Arctic Canada the foreland basin is still preserved, however, and consists of an enormous clastic wedge initiated by early Middle Devonian time (Embry, in press). However, the Ellesmerian tectono-metamorphic zones show a striking parallelism to the thermal maturity pattern of Lower Cambrian and Lower Silurian source rock intervals (Fig. 9). The maturity increases markedly from immature-early mature in the south to post-mature in the north over only $10-30 \mathrm{~km}$ as the fold belt is approached (Christiansen, 1989). This strong gradient is interpreted as corresponding to the position of the Ellesmerian thrust front, and the proximal foreland basin. The maturity pattern thus reflects the combined effects of Silurian basin subsidence, Ellesmerian thrust sheet loading, and loading by the Ellesmerian foreland basin. South of the high maturity gradient the foreland basin decreased in thickness and it was probably only about $1 \mathrm{~km}$ thick at the $T_{\max } 400$ iso-contour line (Fig. 9D).

\section{0, Late Palaeozoic rift basin, 360-260 Ma}

The later Palaeozoic history of North Greenland following the mid-Palaeozoic Ellesmerian Orogeny and foreland basin formation is poorly known. The main outcrop area of younger rocks is in eastern Peary Land and in northern Kronprins Christian Land, Amdrup Land and Holm Land (Fig. 1). In the remaining part of North Greenland younger rocks are only preserved in a few narrow fault blocks in the Harder Fjord Fault Zone and in the Kap Cannon Thrust Zone on the north coast of Peary Land (Fig. 1).

These rocks range in age from Early Carboniferous to Tertiary and have previously been described under one term, the Wandel Sea Basin (Dawes \& Soper, 1973). It is clear from recent work that this single concept is inappropriate, and it is now recognised that a long series of basin-forming events occurred under different stress regimes (Håkansson \& Stemmerik, 1989; Stemmerik \& Håkansson, 1991). During the Late Palaeozoic, deposition took place in two largely independent basins, de- scribed as the North Greenland - Svalbard rift basin and the East Greenland - West Norway rift basin, respectively (Håkansson \& Stemmerik, 1989; Fig. 3). In the present context the Wandel Sea Basin is considered roughly synonymous with the former basin, and it should be understood that it only exposes the marginal facies of an extensive basin between eastern North Greenland and Svalbard.

Continental sedimentation was initiated in North Greenland during the Early Carboniferous with deposition of $600 \mathrm{~m}$ of fine-grained sediments of flood-plain origin in southern Holm Land at the northern end of the East Greenland rift basin (Figs 1, 3G, 4). This phase was followed by faulting, uplift and erosion. In the Late Carboniferous (early Moscovian) marine sedimentation commenced in small fault blocks in Holm Land and Amdrup Land delimited to the west by a major N-S trending fault zone and by NW-SE cross-faults. The Late Carboniferous (early Moscovian) transgression resulted in submergence of southern Amdrup Land and the whole region east and north of the East Greenland, Trolle Land and Harder Fjord Fault Zones in late Moscovian - Gzelian time (Fig. 3G).

During Late Carboniferous times shelf deposition was dominated by interbedded sandstone, shale and carbonate. In the latest Carboniferous a general sealevel rise led to the development of an extensive carbonate platform which persisted through the Early Permian.

This regime was brought to an end in mid-Permian times, and the carbonate platform was drowned by an influx of siliciclastic sediments. This change may be related to a major change in oceanographic circulation following the important mid-Permian phase of extensional block faulting and rotation known from the East Greenland basin (Surlyk et al., 1986). Contemporaneous coarse-clastic alluvial deposits formed in small faultbound basins in the Harder Fjord Fault Zone.

The Upper Permian succession of the Trolle Land Group consists of shale and chert forming thickly developed (1000-1200 m) shallowing-upwards cycles reflecting basin subsidence along the Trolle Land and Harder Fjord Faults associated with a general Late Permian sea-level fall. The marked mid-Permian facies changes reflect large-scale plate reorganisation concurrent with the final stages of Uralian fusion (Stemmerik \& Worsley, 1989). At this time the important seaway between the Boreal Ocean and the European Zechstein Basin was established along the system of submerged intracratonic rifts in the area between Greenland and Norway.

Both the continental and marine Late Palaeozoic successions show a pronounced cyclity on several scales (Stemmerik \& Worsley, 1989). Contemporaneous cyclic 
deposits are well known from many parts of the world and most probably reflect eustatic sea-level fluctuations induced by repeated glaciation (see review in Miall, 1990). Major regressive events may thus correspond to times of exceptionally widespread Gondwanan glaciations. The smaller cycles may be within the Milankovitch frequency band and thus due to astronomical forcing. Major cycle boundaries are recorded in the midMoscovian, latest Gzelian, at the Kungurian-Ufimian boundary, near the Kazanian-Tatarian boundary, and at the Permian-Triassic boundary.

\section{1, Mesozoic oblique-slip basin, 250-80 Ma}

The Mesozoic history of central and eastern North Greenland reflects basin development in a different stress field from the Late Palaeozoic (Fig. $3 \mathrm{H}$ ). Small fault-block sub-basins were formed in a NW-SE trending oblique-slip belt extending from Kronprins Christian Land to eastern Peary Land. These faults may extend south-eastwards across the present shelf and relate directly to the developing Spitzbergen Fracture Zone (Håkansson et al., 1991).

During much of the Mesozoic the area between Greenland and Norway was characterised by phases of roughly E-W extension. At the northern end of this major rift basin the extension was relieved by oblique slip along the nascent Spitzbergen Fracture Zone. Phases of transpression alternated with basin forming phases of transtension along this mainly dextral obliqueslip zone.

Triassic rocks are only known from a small area in eastern Peary Land where they unconformably overlie Upper Permian deposits. This marine succession is up to $1000 \mathrm{~m}$ thick, and comprises two upwards-coarsening progradational cycles (Parish Bjerg and Dunken Formations). The age is not well known, but seems to fall within the early part of the Triassic (Scythian-Anisian). This is roughly contemporaneous with the only marine Triassic deposits in East Greenland, the Wordie Creek Formation. It is thus possible that the absence of younger Triassic deposits in North Greenland is primary, reflecting the same overall low sea-level stand.

Deposition was only resumed with the onset of the Late Jurassic transgression. In eastern Peary Land the onlapping Middle Oxfordian - Valanginian Ladegårdsåen Formation (more than $250 \mathrm{~m}$ thick) mainly consists of marine fine-grained sediments, except for an Early Valanginian progradational pulse of non-marine sandstone. A more southern sub-basin in Kronprins Christian Land started to receive about $900 \mathrm{~m}$ of mainly restricted marine fine-grained sediments in the Early
Kimmeridgian, and fully marine conditions were only reached in the Early Valanginian.

Facies development in the individual pull-apart basins is remarkably different, reflecting differences in tectonic events and subsidence patterns over short distances.

Early Cretaceous (Aptian-Albian) marine deposits, up to $650 \mathrm{~m}$ thick, are only known from a few occurrences in Kronprins Christian Land, with an outlier as far west as Valdemar Glückstadt Land.

In Late Cretaceous times a major pull-apart basin developed, and six local blocks or sub-basins have been recognised along the oblique-slip belt (Håkansson et al., 1991). With few exceptions they show different stratigraphic developments and were initiated at different times, although a tendency to progressive younging towards the north-west was noted by Birkelund \& Håkansson (1983). The two westernmost sub-basins contain the only evidence of magmatic activity, and one sub-basin is almost entirely volcanic.

The facies of the individual sub-basins are markedly different. Thus, more than $1500 \mathrm{~m}$ of marine shallowing-upwards deposits of Middle Turonian - Early Coniacian or younger age accumulated in northern Kronprins Christian Land. Deposition was followed by strong transpressional deformation and development of domal folds and thrusts.

In a neighbouring basin the development was quite different and more than $600 \mathrm{~m}$ of Late Cretaceous finegrained marine sandstones were deposited and later subjected to a short-lived pulse of increase in heat flow leading to low greenschist metamorphism. A highly sheared and deformed Late Santonian succession, some $400 \mathrm{~m}$ thick, occurs in the Harder Fjord Fault Zone. Strongly deformed fluviatile sandstones and shales of probable Late Cretaceous age also occur in close association with the Harder Fjord and Trolle Land Fault Zones.

\section{2, Rifting of the Eurasia basin, 80-65 Ma}

A succession of at least $5 \mathrm{~km}$ of volcanic extrusive rocks and interbedded sediments constituting the Kap Washington Group is exposed in south-easterly inclined thrust wedges on the north coast of Greenland (Figs 1, 4). The suite is of peralkaline provenance and includes rhyolitic lavas and pyroclastic flows, trachytic and basaltic lavas, as well as tuffs, agglomerates and breccias (Brown \& Parsons, 1981). The age is somewhat uncertain, but palaeobotanic evidence indicates a Late Cretaceous age for the volcanic activity, probably mainly in the interval from Campanian to the Maas- 
trichtian-Danian boundary (Batten et al., 1981; Håkansson et al., 1991).

A dense swarm of N-S trending late Cretaceous dolerite dykes occurs in the area south of the Kap Washington volcanics. South of the Harder Fjord Fault Zone the $\mathrm{N}-\mathrm{S}$ swarm is replaced by a less dense suite of WNW trending dykes, and further south, in Peary Land, by a NW trending set. The main, N-S swarm was formed during a period of E-W extension of mainly continental crust, preceding the opening of the Eurasia basin (e.g. Soper \& Higgins, in press b). The NW trending swarm shows a remarkable parallelism with the Trolle Land Fault Zone and may reflect extensional events during basin formation to the east.

\section{3, Eurekan thrusting and faulting, 65-55 Ma}

The volcanic episoede was followed by the development in Palaeocene-Eocene time of the SE-dipping Kap Cannon Thrust Zone. This has been interpreted as a Eurekan compressional, within-plate, response to the anticlockwise rotation of Greenland due to spreading in the Labrador Sea (Soper \& Higgins, in press b), or may have formed in conjunction with transpression during dextral NW-SE strike-slip movements (Håkansson \& Pedersen, 1982).

On a larger plate tectonic scale it is possible that these two interpretations can be united when more precise datings become available.

\section{4, Early Tertiary initiation of transform margin, 55-0 Ma}

Tertiary sediments of the Thyra $\emptyset$ Formation only occur in northernmost Kronprins Christian Land and on the islands south-east of Peary Land (Figs 1-4). The formation is up to $50 \mathrm{~m}$ thick in outcrop and consists of gravel, sand, silt and abundant coal seams deposited in a broad flood-plain. The sediments have not undergone any deformation and thus post-date the transpressional events characterising the Mesozoic basin. Their age is probably Late Palaeocene. They represent the earliest ocean margin sediments formed when the stress in the Wandel Sea area was relieved by onset of spreading of the Norwegian-Greenland Sea (see review by Larsen, 1990; Fig. 3I).

The Thyra $\emptyset$ Formation contains the youngest preQuaternary deposits of North Greenland and marks the end of a long succession of independent tectonostratigraphic basins formed during alternating extensional and compressional episodes.

\section{Summary}

Tectonostratigraphy describes sedimentary basins formed during major events of plate reorganisation. In North Greenland tectonostratigraphic basins include an interior sag basin (Middle Proterozoic), two rift-to-passive margin basins (Late Proterozoic and Early Palaeozoic), two foreland basins (mid-Palaeozoic, both removed by later uplift and erosion), an intracontinental rift basin (Late Palaeozoic), an oblique-slip pull-apart basin complex (Mesozoic), and a poorly preserved proximal transform margin basin (Early Tertiary).

The tectonostratigraphic basins cover a span of time of more than 1200 million years from the Middle Proterozoic to the Early Tertiary. The exact nature of the earliest recognised tectonostratigraphic unit, the Middle Proterozoic Independence Fjord basin (c. $1380 \mathrm{Ma}$ ), is poorly known. It overlies Archaean crystalline basement, and the great uniformity and lateral extent of the continental sandstones and thin siltstones constituting the basin fill suggest that it is an interior sag basin. Rifting and early spreading occurred around $1230 \mathrm{Ma}$ and is represented by the Midsommers $\emptyset$ - Zig-Zag Dal volcanic event.

A phase of trough subsidence, faulting and peneplanation followed which may be interpreted as reflecting closure of an ocean during the Grenvillian Orogeny (1100-1000 Ma) well known from Arctic Canada.

Rifting and spreading of the Iapetus Ocean was initiated in Late Proterozoic times between 800 and $570 \mathrm{Ma}$. The Late Proterozoic Hagen Fjord - Rivieradal Basin which was deposited within this time-interval may thus represent a shelf-slope-proximal basin of the Iapetus passive margin. Remnants of a Varangian glacial succession belong to this tectonostratigraphic unit.

Rifting of the Franklinian Basin took place close to the Proterozoic-Cambrian boundary (between 640 and $570 \mathrm{Ma}$ ). Onset of spreading and formation of a remarkably well preserved E-W trending passive margin succession continued through Cambrian, Ordovician and Silurian times.

The eastern passive margin was influenced by the westwards migration of a peripheral bulge reflecting an early closing event in the Iapetus Ocean and accretion of a micro-continent. This event terminated in the Early Ordovician (c. $500 \mathrm{Ma})$ and the regular evolution of the Franklinian Basin continued.

Final closure of the Iapetus Ocean took place during the Silurian, and the onset of Caledonian orogenic uplift in the Early Silurian is reflected by rapid westwards outbuilding in the Franklinian deep-water basin of the huge Peary Land deep-sea fan sourced from the rising Caledonian mountain belt. The Franklinian shelf rap- 
idly foundered by flexural bending caused by basinal loading of the enormous volumes of deep-sea fan deposits. The foundering of the platform was aided by a major eustatic rise in the Late Llandovery.

Final suturing of the Iapetus Ocean took place close to the Silurian-Devonian boundary (c. $410 \mathrm{Ma}$ ) and was marked by westwards transport of nappes. Loading by a pile of nappes at least $5 \mathrm{~km}$ thick caused flexural downbending of the eastern part of the Franklinian shelf and the formation of a roughly $\mathrm{N}-\mathrm{S}$ trending foreland basin. The latter is not preserved due to later uplift and erosion. Its former presence is revealed by a pronounced change in the trend in maturity iso-lines from E-W, parallel to the Franklinian margin, to N-S, parallel to the Caledonian front in eastern areas of North Greenland.

Iapetus suturing was followed by closure of the Franklinian Basin in Late Devonian - Early Carboniferous time (c. $360 \mathrm{Ma}$ ). Loading of the Franklinian slope and shelf region by Ellesmerian thrust sheets caused flexural down-bending and formation of an E-W trending Ellesmerian foreland basin. This tectonostratigraphic basin is not preserved but its former presence is revealed by maturity parameters. The position of the thrust front and the proximal foreland basin is indicated by a marked increase in the S-N maturity gradient over a short distance.

A continental rift basin was formed in the Early Carboniferous. It represents the northernmost extension of the Late Palaeozoic rift basin of East Greenland and intersects the eastern part of the Franklinian Basin in eastern North Greenland. It was followed by faulting, uplift and erosion, succeeded by marine onlap in Late Carboniferous, Moscovian time (c. $300 \mathrm{Ma}$ ). Rifting culminated in the mid-Permian, as in central East Greenland, and the Late Palaeozoic carbonate platform was drowned during the event.

During the Mesozoic a new type of tectonostratigraphic basin developed mainly caused by extensional oblique slip in the weakness zone in the Barents Shelf between eastern North Greenland and Svalbard. A NW-SE trending pull-apart basin complex was initiated in the Triassic. Early and Middle Jurassic rocks are not preserved or were never deposited, and marine onlap started in the Late Jurassic, concomitant with a major eustatic rise in sea-level. Transtensional and transpressional events alternated during the Cretaceous.

Opening of the Eurasia Basin is reflected by N-S, WNW-ESE and NW-SE dyke swarms and interbedded volcanic extrusives and sediments of the Late Cretaceous Kap Washington Group. This unit was overthrust by Late Palaeozoic rocks during the Kap Cannon thrusting event which possibly represents a Eurekan within- plate response to the anticlockwise rotation of Greenland due to spreading in the Labrador Sea.

The stress between eastern North Greenland and Svalbard was relieved by the onset of spreading of the Norwegian-Greenland Sea in the Palaeocene and the youngest pre-Quaternary tectonostratigraphic basin in North Greenland is represented by thin undeformed Palaeocene proximal transform margin deposits. They mark the end of a long succession of tectonostratigraphic basins formed as a consequence of major plate tectonic events and changes in plate configuration.

Acknowledgements. I am grateful to F. G. Christiansen, A. K. Higgins, E. Håkansson, H. F. Jepsen, L. Stemmerik and M. Sønderholm for placing unpublished information and manuscripts at my disposal and for critically reading parts or all of the manuscript. M. Sønderholm, in particular, gave a thorough review of the first draft. D. Pugliese, T. Damholt, B. Sikker Hansen and Bente Thomas are thanked for assistance in preparation of the manuscript.

\section{References}

Batten, D. J., Brown, P. E., Dawes, P. R., Higgins, A. K., Koch, B. E., Parsons, I. \& Soper, N. J. 1981: Peralkaline volcanicity on the Eurasia Basin margin. Nature 294, 150152.

Birkelund, T. \& Hăkansson, E. 1983: The Cretaceous of North Greenland - a stratigraphic and biogeographical analysis. Zitteliana 10, 7-25.

Brown, P. E. \& Parsons, I. 1981: The Kap Washington Group Volcanics. Rapp. Grønlands geol. Unders. 106, 65-68.

Bryant, I. D. \& Smith, M. P. 1990: A composite tectoniceustatic origin for shelf sandstones at the Cambrian-Ordovician boundary in North Greenland. J. geol. Soc. Lond. 147, 795-809.

Christiansen, F. G. (ed.) 1989: Petroleum geology of North Greenland. Bull. Gronlands geol. Unders. 158, 92 pp.

Clemmensen, L. B. \& Jepsen, H. F. in press: Lithostratigraphy and geological setting of Upper Proterozoic shelf deposits, Hagen Fjord Group, eastern North Greenland. Rapp. Grønlands geol. Unders.

Collinson, J. D. 1983: Sedimentology of unconformities within a fluvio-lacustrine sequence; Middle Proterozoic of eastern North Greenland. Sediment. Geol. 34, 145-166.

Collinson, J. D., Bevins, R. E. \& Clemmensen, L. B. 1989: Post-glacial mass flow and associated deposits preserved in palaeovalleys: the Late Precambrian Morænesø Formation, North Greenland. Meddr Grønland Geosci. 21, 26 pp.

Dawes, P. R., Larsen, O. \& Kalsbeek, F. 1988: Archaean and Proterozoic crust in North-West Greenland: evidence from Rb-Sr whole rock age determinations. Can. J. Earth Sci. 25, 1365-1373.

Dawes, P. R. \& Soper, N. J. 1973: Pre-Quaternary history of North Greenland. In Pitcher, M. G. (ed.) Arctic geology. Mem. Am. Ass. Petrol. Geol. 19, 117-134. 
Embry, A. F. in press: Middle-Upper Devonian clastic wedge of the Arctic islands. In Trettin, H. P (ed.) Innuitian Orogen and Arctic Platform; Canada and Greenland. Geology of Canada 3. Geol. Surv. Canada (also The geology of North America E, Boulder, Colorado: Geol. Soc. Amer.).

Falvey, D. A. \& Middleton, M. F. 1981: Passive continental margins: evidence for a prebreakup deep crustal metamorphic mechanism. Oceanologica Acta 4, Supp. 103-114 (Publ. 26th int. geol. Congr. Paris 1980. Collogue C3, Geology of continental margins).

Hảkansson, E. \& Pedersen, S. A. S. 1982: Late Paleozoic to Tertiary tectonic evolution of the continental margin in North Greenland. In Embry, A. F. \& Balkwill, H. R. (ed.) Arctic geology and geophysics. Mem. Can. Soc. Petrol. Geol. 8, 331-348.

Håkansson, E. \& Stemmerik, L. 1989: Wandel Sea basin - a new synthesis of the late Paleozoic to Tertiary accumulation in North Greenland. Geology 17, 683-686.

Håkansson, E., Heinberg, C. \& Stemmerik, L. 1991: Mesozoic and Cenozoic history of the Wandel Sea Basin area, North Greenland. Bull. Grønlands geol. Unders. 160 (this volume).

Hansen, B. T., Kalsbeek, F. \& Holm, P. M. 1987: Archaean age and Proterozoic metamorphic overprinting of the crystalline basement at Victoria Fjord, North Greenland. Rapp. Grønlands geol. Unders. 133, 159-168.

Henriksen, N. \& Higgins, A. K. 1991: The North Greenland project. Bull. Grønlands geol. Unders. 160 (this volume).

Higgins, A. K. 1986: Geology of central and eastern North Greenland. Rapp. Gronlands geol. Unders. 128, 37-54.

Higgins, A. K., Friderichsen, J. D. \& Soper, N. J. 1981: The North Greenland fold belt between central Johannes V. Jensen Land and eastern Nansen Land. Rapp. Grønlands geol. Unders. 106, 35-45.

Higgins, A. K., Ineson, J. R., Peel, J. S., Surlyk, F. \& Sønderholm, M. 1991: Lower Palaeozoic Franklinian Basin of North Greenland. Bull. Grønlands geol. Unders. 160 (this volume).

Hurst, J. M., Jepsen, H. F., Kalsbeek, F., McKerrow, W. S. \& Peel, J. S. 1985: The geology of the northern extremity of the East Greenland Caledonides. In Gee, D.G. \& Sturt, B.A. (ed.) The Caledonide Orogen-Scandinavia and related areas, 1047-1063. London: John Wiley \& Sons Ltd.

Hurst, J. M. \& McKerrow, W. S. 1981: The Caledonian nappes of East Greenland. Nature 290, 772-774.

Hurst, J. M., McKerrow, W. S., Soper, N. J. \& Surlyk, F. 1983: The relationship between Caledonian nappe tectonics and Silurian turbidite deposition in North Greenland. $J$. geol. Soc. Lond. 140, 123-131.

Hurst, J. M. \& Surlyk, F. 1982: Stratigraphy of the Silurian turbidite sequence of North Greenland. Bull. Grønlands geol. Unders. 145, $121 \mathrm{pp}$.

Jackson, G. $\Gamma$ \& Ianclli, T. 1981: Rift-related cyclic sedimentation in the Neohelikian Borden Basin, northern Baffin Island. In Campbell, F. H. A. (ed.) Proterozoic basins of Canada. Pap. geol. Surv. Can. 81-210, 269-302.

Johnson, M. E., Rong, J.-Y. \& Yang, X.-C. 1985: Intercontinental correlation by sea-level events in the Early Silurian of North America and China (Yangtze Platform). Bull. geol. Soc. Am. 96, 1384-1397.
Kalsbeek, F. \& Jepsen, H. F. 1983: The Midsommersø Dolerites and associated intrusions in the Proterozoic platform of eastern North Greenland - a study of the interaction between intrusive basic magma and sialic crust. J. Petrol. 24, $605-634$.

Kalsbeek, F. \& Jepsen, H. F. 1984: The Late Proterozoic Zig-Zag Dal Basalt Formation of eastern North Greenland. J. Petrol. 25, 644-664.

Larsen, H. C. 1990: The East Greenland Shelf. In Grantz, A., Johnson, L. \& Sweeney, J. F. (ed.), The Arctic Ocean region, The Geology of North America. L, 185-210. Boulder, Colorado: Geol. Soc. Amer.

Long, D. G. F. 1989a: Kennedy Channel Formation: key to the early history of the Franklinian continental margin, central eastern Ellesmere Island, Arctic Canada. Can. J. Earth Sci. 26, 1147-1159.

Long, D. G. F. 1989b: Ella Bay Formation: Early Cambrian shelf differentiation in the Franklinian basin, central eastern Ellesmere Island, Arctic Canada. Can. J. Earth Sci. 26, 2621-2635.

McKenzie, D. 1978: Some remarks on the development of sedimentary basins. Earth planet. Sci. Lett. 40, 25-32.

Miall, A. D. 1990: Principles of sedimentary basin analysis, 668 pp. New York: Springer-Verlag New York Inc.

Parsons, I. 1981: Volcanic centres between Frigg Fjord and Midtkap, eastern North Greenland. Rapp. Gronlands geol. Unders. 106, 69-75.

Pedersen, S. A. S. 1986: A transverse, thin-skinned, thrustfault belt in the Paleozoic North Greenland fold belt. Bull. geol. Soc. Am. 97, 1442-1455.

Pedersen, S. A. S. \& Holm, P. M. 1983: The significance of a Middle Devonian $\mathrm{K} / \mathrm{Ar}$ age of an intrusive rock in the southern part of the North Greenland Fold Belt. Bull. geol. Soc. Denmark 31, 121-127.

Peel, J. S., Dawes, P. R., Collinson, J. D. \& Christie, R. L. 1982: Proterozoic - basal Cambrian stratigraphy across Nares Strait: correlation between Inglefield Land and Bache Peninsula. In Dawes, P. R. \& Kerr, J. W. (ed.) Nares Strait and the drift of Greenland: a conflict in plate tectonics. Meddr Gronland Geosci. 8, 105-115.

Sønderholm, M. \& Harland, T. L. 1989: Franklinian reef belt, Silurian, North Greenland. In Geldsetzer, H. H. J., James, N. P. \& Tebbutt, G. E. (ed.) Reefs, Canada and adjacent area. Mem. Can. Soc. Petrol. Geol. 13, 356-366.

Sønderholm, M. \& Jepsen, H. F. 1991: Proterozoic basins of North Greenland. Bull. Grønlands geol. Unders. 160 (this volume).

Soper, N. J. \& Higgins, A. K. 1985: Thin-skinned structures at the basin-shelf transition in North Greenland. Rapp. Gronlands geol. Unders. 126, 87-94.

Soper, N. J. \& Higgins, A. K. 1987: A shallow detachment beneath the North Greenland fold belt: implications for sedimentation and tectonics. Geol. Mag. 124, 441-450.

Soper, N. J. \& Higgins, A. K. 1990: Models for the Ellesmerian mountain front in North Greenland: a basin margin inverted by basement uplift. J. struct. Geol. 12, 83-97.

Soper, N. J. \& Higgins, A. K. in press a: Late Silurian or Devonian to early Carboniferous deformation and meta- 
morphism, North Greenland. In Trettin, H. P. (ed.) The Innuitian Orogen and Arctic Platform; Canada and Greenland. Geology of Canada 3. Ottawa: Geol. Surv. Canada (also The geology of North America E, Boulder, Colorado: Geol. Soc. Amer.).

Soper, N. J. \& Higgins, A. K. (in press b): Late Cretaceous Early Tertiary deformation, North Greenland. In Trettin, H. D. (ed.) The Innuitian Orogen and Arctic Platform; Canada and Greenland. Geology of Canada 3. Ottawa: Geol. Surv. Canada (also The geology of North America E, Boulder, Colorado: Geol. Soc. Amer.).

Stemmerik, L. \& Håkansson, E. 1991: Carboniferous and Permian history of the Wandel Sea Basin, North Greenland. Bull. Gronlands geol. Unders. 160 (this volume).

Stemmerik, L. \& Worsley, D. 1989: Late Palaeozoic sequence correlations, North Greenland, Svalbard and the Barents Shelf. In Collinson, J. D. (ed.) Correlation in hydrocarbon exploration, 99-111. London: Graham \& Trotman for the Norwegian Petroleum Society.

Surlyk, F. 1982: Nares Strait and the down-current termination of the Silurian turbidite basin of North Greenland. In Dawes, P. R. \& Kerr, J. W. (cd.) Nares Strait and the drift of Greenland: a conflict in plate tectonics. Meddr Grønland Geosci. 8, 147-150.

Surlyk, F. 1988: Iapetus closure reflected in Cambro-Silurian Franklinian basin evolution. Program abstr. geol. Ass. Can. 13, A 121 only.

Surlyk, F. \& Hurst, J. M. 1983: Depositional environments along a carbonate ramp to slope transition in the Silurian of Washington Land, North Greenland. Can. J. Earth Sci. 20, 473-499.
Surlyk, F. \& Hurst, J. M. 1984: The evolution of the early Palaeozoic deep-water basin of North Greenland. Bull. geol. Soc. Am. 95, 131-154.

Surlyk, F., Hurst, J. M. \& Bjerreskov, M. 1980: First agediagnostic fossils from the central part of the North Greenland foldbelt. Nature 286, 800-803.

Surlyk, F., Hurst, J. M. Piasecki, S., Rolle, F. Scholle, P. A., Stemmerik, L. \& Thomsen, E. 1986: The Permian of the western margin of the Greenland Sea - A future exploration target. In Halbouty, M. T. (ed.) Future petroleum provinces of the world. Mem. Am. Ass. Petrol. Geol. 40, 629-659.

Surlyk, F. \& Ineson, J. R. 1987a: Aspects of Franklinian shelf, slope and trough evolution and stratigraphy in North Greenland. Rapp. Grønlands geol. Unders. 133, 41-58.

Surlyk, F. \& Ineson, J. R. 1987b: The Navarana Fjord Member (new) - an Upper Llandovery platform derived carbonate conglomerate. Rapp. Grønlands geol. Unders. 133, 59-63.

Thon, A. 1985: Late Ordovician and Early Silurian cover sequences to the west Norwegian ophiolite fragments: stratigraphy and structural evolution. In Gee, D. E. \& Sturt, B. A. (ed.) The Caledonide Orogen - Scandinavia and related areas, 407-415. London: John Wiley \& Sons Ltd.

Trettin, H. P. 1987: Pearya: a composite terrane with Caledonian affinities in northern Ellesmere Island. Can. J. Earth Sci. 24, 224-245.

Trettin, H. P. 1989: The arctic islands. In Bally, A. W. \& Palmer, A. R. (ed.) The geology of North America A, 349370. Boulder, Colorado: Geol. Soc. Amer.

Williams, H. \& Hatcher, R. D. Jr. 1983: Appalachian suspect terranes. In Hatcher, R. D. Jr., Williams, H. \& Zietz, I. (ed.) Contributions to the tectonics and geophysics of mountain chains. Mem. geol. Soc. Amer., 158, 33-53. 

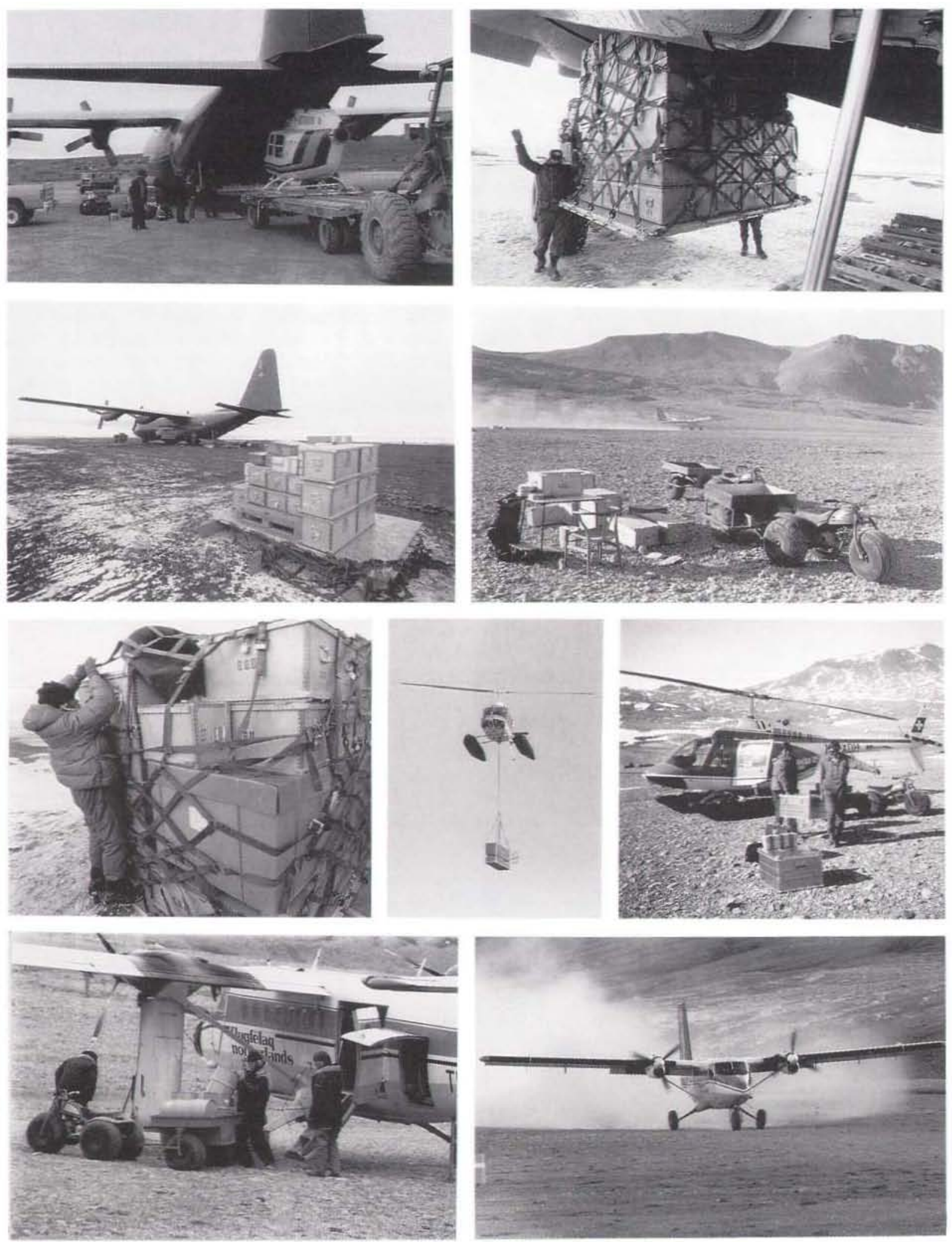

The North Greenland Project: transportation of the expedition and daily logistics. 